\title{
Stereochemical Studies. X.1) Effects of Neighboring Functional Groups on 1,2-Asymmetric Induction in the Reduction of Propiophenone Derivatives with Sodium Borohydride ${ }^{2)}$
}

\author{
Kenji Koga and Shun-Ichi Yamada \\ Faculty of Pharmaceutical Sciences, University of Tokyo ${ }^{3}$
}

(Received September 21, 1971)

\begin{abstract}
Effects of neighboring functional groups on 1,2-asymmetric induction in sodium borohydride reduction were examined with eight kinds of ketones (I-VIII) having functional groups, such as $-\mathrm{NH}_{2} \mathrm{HCl},-\mathrm{OH}$, and $-\mathrm{OCH}_{3}$, at $\alpha$ - and/or $\beta$-positions to the carbonyl group. It was recognized that the stereochemical course of the reduction was highly dependent on the position of these functional groups, i.e. erythro-rich products were obtained in reduction of ketones having a functional group at $\alpha$-position to the carbonyl group, while threo-rich products were obtained in reduction of ketones having a functional group at $\beta$-position to the carbonyl group. A six-membered empirical model (XXXVII) was proposed for predicting the stereochemical course in the reduction of ketones having a functional group at $\beta$-position to the carbonyl group.

Determinations of the relative configurations of the diastereomers (X, XI, XII, $\mathrm{XIV}, \mathrm{XV}$, and $\mathrm{XVI}$ ) were also performed.
\end{abstract}

Numerous investigations ${ }^{4,5)}$ have been done on kinetically controlled 1,2-asymmetric induction in acylic ketones having one asymmetric center adjacent to the carbonyl group. To account for the stereochemical outcomes of these studies, three general explanations evaluating the transition states of the lowest energy have been advanced. ${ }^{4 c}$ In the first, three empirical models of reactant-like transition states were proposed, depending upon the substituents attached to the adjacent asymmetric center. Thus, an open chain model is

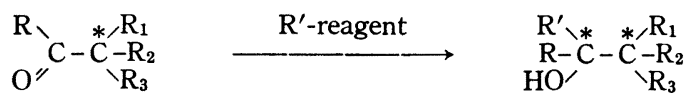

applied when the three substituents are all alkyl, aryl, or hydrogen, ${ }^{5 a)}$ a cyclic model is applied when one of the substituents is hydroxy, methoxy, or amino group, ${ }^{5 d, e, o)}$ and a dipolar model is applied when one of the substituents is a halogen. ${ }^{5 c, g)}$ In the second explanation, ${ }^{5 h, i}$. models of reactant-like transition states, in which one of the substituents attached to the asymmetric center eclipses the carbonyl oxygen, are considered. Approaches to semi-quantitative prediction of product stereospecificities have also been made by the energetic evaluation of the

1) Part IX: K. Hiroi, K. Achiwa, and S. Yamada, Chem. Pharm. Bull. (Tokyo), 20, 246 (1972).

2) For a preliminary communication on this work, see S. Yamada and K. Koga, Tetrahedron Letters, 1967, 1711.

3) Location: Hongo, Bunkyo-ku, Tokyo.

4) a) J.I. Klabunowski, "Asymmetrische Synthese," Deutscher Verlag der Wissenschaften, Berlin, 1963; b) D.R. Boyd and M.A. McKervey, Quart. Rev. (London), 22, 95 (1968); c) S. Yamada and K. Koga, "Selective Organic Transformations," Vol. 1, ed. by B.S. Thyagarajan, Wiley-Interscience, New York, 1970, p. 1.

5) a) D.J. Cram and F.A. Abd Elhafez, J. Am. Chem. Soc., 74, 5828 (1952); b) J. Sicher, M. Svoboda, M. Hrdá, J. Rudinger, and F. Šorm, Collection Czech. Chem. Commun., 18, $487(1953)$; c) J.W. Cornforth, R.H. Cornforth, and K.K. Mathew, J. Chem. Soc., 1959, 112; d) D.J. Cram and K.R. Kopecky, J. Am. Chem. Soc., 81, 2748 (1959); e) J.H. Stocker, P. Sidithunthorn, B.M. Benjamin, and C.J. Collins, ibid., 82, $3913(1960)$; f) T. Matsumoto, T. Nishida, and H. Shirahama, J. Org. Chem., 27, $79(1962) ; g)$ D.J. Cram and D.R. Wilson, J. Am. Chem. Soc., 85, 1245 (1963); h) G.J. Karabatsos, ibid., 89, 1367 (1967); i) G.J. Karabatsos and T.H. Althuis, Tetrahedron Letters, 1967, 4991; j) M. Cherest, H. Felkin, and N. Prudent, ibid., 1968, 2199. 
models when the substituents attached to the asymmetric center are all alkyl, aryl, or hydrogen. In the third explanation, ${ }^{5 j}$ ) the direction and the degree of 1,2-asymmetric induction are considered to be determined by the relative stabilities of the reactant-like transition states of the staggered conformations in which tortional strains and steric strains are evaluated to be most important.

A previous paper from our laboratory reported ${ }^{6}$ ) that sodium borohydride reduction of $\mathrm{N}(\alpha$-methylphenacyl)benzamide in ethanol at room temperature gave a mixture of diastereomers, in which erythro-isomer (N-benzoylnorephedrine) predominated over threo-isomer (Nbenzoyl-nor-pseudo-ephedrine). Using the above explanations, the stereochemical course of this reduction was considered to be influenced by the neighboring amide group attached to the asymmetric center. ${ }^{6}$ As we are interested in the influences of neighboring functional groups on the direction and the degree of 1,2-aysmmetric induction, eight kinds of ketones (I-VIII) with oxygen- and nitrogen-functional groups at $\alpha$-and/or $\beta$-positions to the carbonyl group were selected as substrates (see Table I) and their stereochemical outcomes in sodium borohydride reduction were examined.")

TABLE I. Starting Materials and Diastereomeric Products

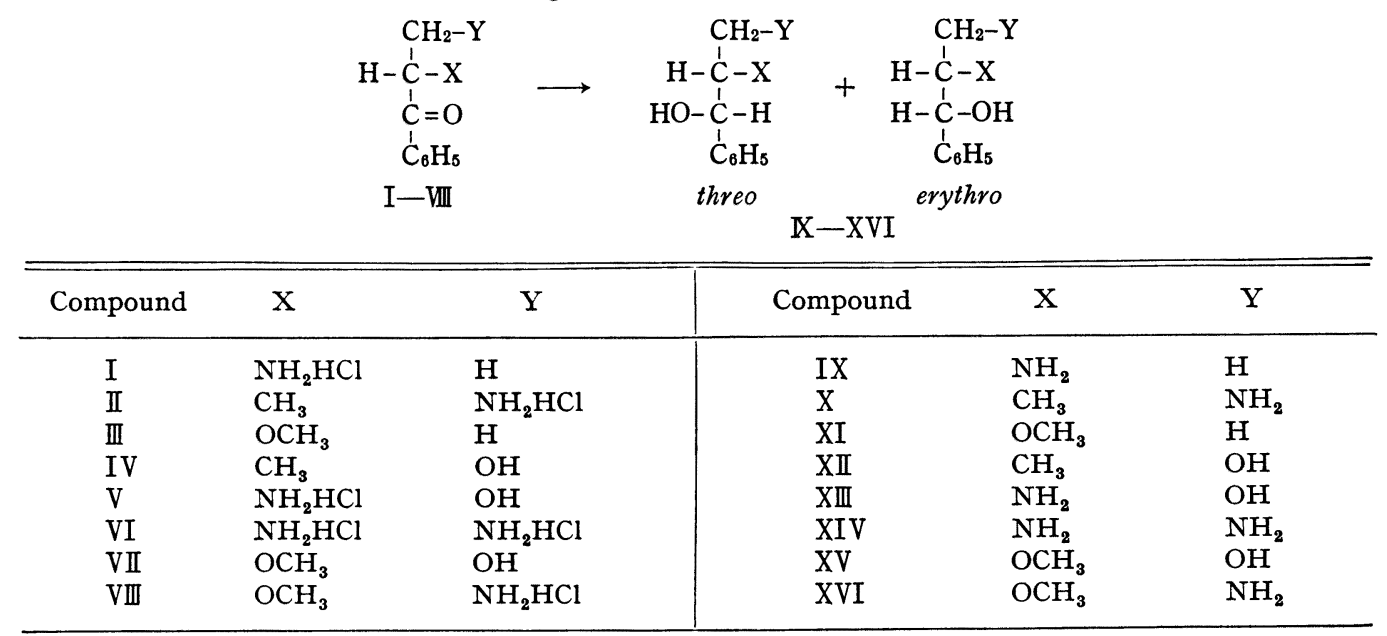

\section{Result and Discussion}

\section{Preparation of Starting Materials}

Of the eight kinds of ketones (I-VIII), I, ${ }^{8)}$ III, ${ }^{\text {9) }} \mathrm{IV},{ }^{10)}$ and $\mathrm{V}^{11)}$ were prepared according to the methods in the literature. The syntheses of II, VI, VII, and VIII are formulated in Chart 1. Thus, II was obtained from IV by chlorination of the hydroxy group with thionyl chloride followed by Gabriel synthesis, VI was obtained from the corresponding di-phthalimide derivative (XVIII) by hydrolysis, and VII was prepared from 2-methoxyacetophenone (XIX) by hydroxymethylation with formalin. Ketone (VIII) was prepared from XX, which was ob-

6) K. Koga, H. Matsuo, and S. Yamada, Chem. Pharm. Bull. (Tokyo), 14, 243 (1966).

7) a) Although Fischer formulae and flying-wedge formulae are used to clarify stereochemical structures, all experiments in this paper were carried out with racemic compounds; $b$ ) To avoid confusion in stereochemical nomenclature, all diastereomeric compounds in this paper are named threo or erythro, based on their representations in Table I.

8) Chr. Schmidt, Ber., 22, 3249 (1899).

9) G.L. Stevens, W. Malik, and R. Platt, J. Am. Chem. Soc., 72, 4758 (1950).

10) H.E. Zimmermann and J. English, Jr., J. Am. Chem. Soc., 76, 2294 (1954).

11) S. Ikuma, Yakugaku Zasshi, 72, 947 (1952). 

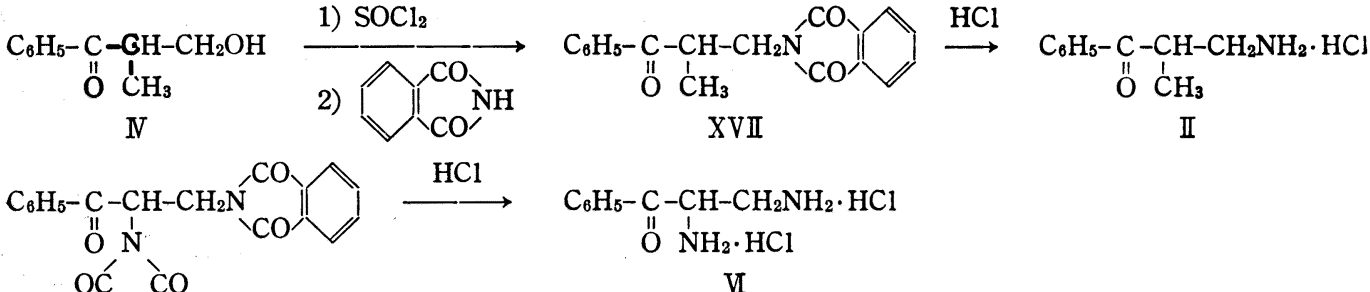

XVIII

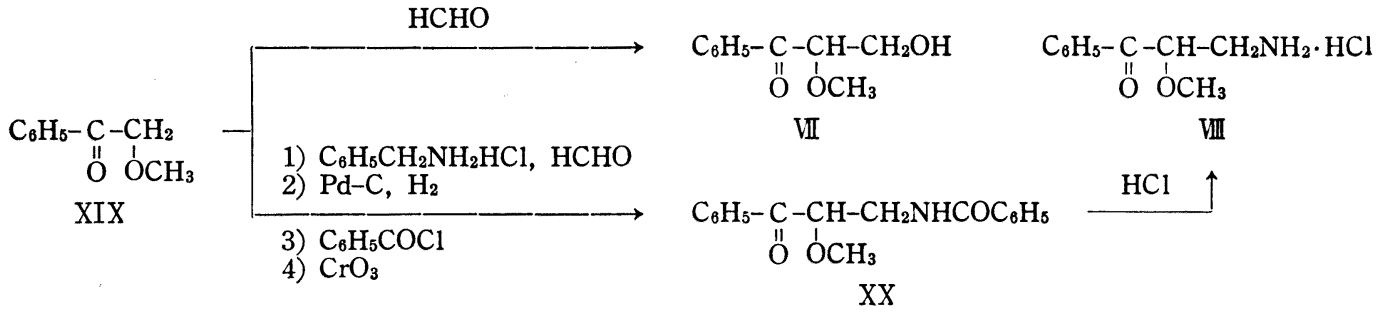

Chart 1. Synthetic Routes of II, VI, VII, and VIII
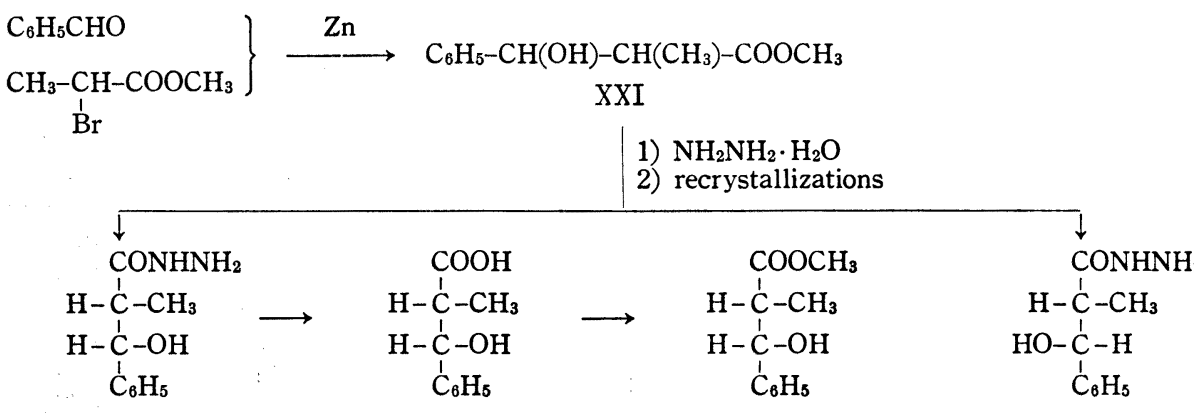

erythro-XXII

$$
\text { erythro-XXIII }
$$

erythro-XXIV

threo-XXII

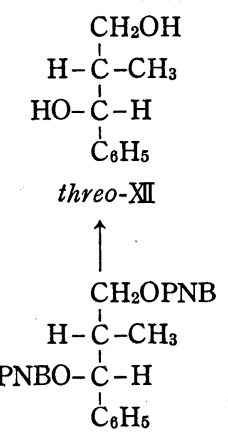

threo-XXVI
1) $\mathrm{NaBH}_{4}$
2) $p-\mathrm{NO}_{2}-\mathrm{C}_{6} \mathrm{H}_{4} \mathrm{COCl}$
3) recrystallizations

$\mathrm{C}_{6} \mathrm{H}_{5}-\mathrm{C}-\mathrm{CH}-\mathrm{CH}_{2} \mathrm{OH}$

$\stackrel{\mathrm{O}}{\mathrm{C}} \mathrm{C}_{3}$

N

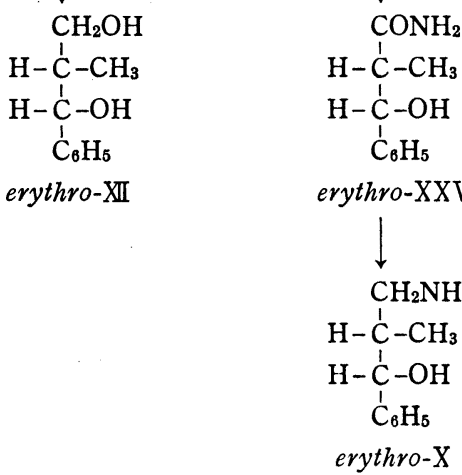

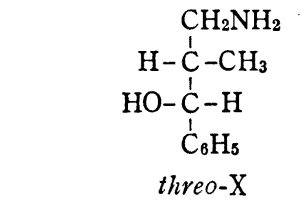

1) $\mathrm{NaBH}_{4}$

2) recrystallizations

$\mathrm{C}_{6} \mathrm{H}_{5}-\mathrm{CO}-\mathrm{CH}-\mathrm{CH}_{2} \mathrm{NH}_{2} \cdot \mathrm{HCl}$ $\mathrm{CH}_{3}$ II

Chart 2. Syntheses and Relative Configurations of X and XII 
tained from XIX by the Mannich reaction with benzylamine hydrochloride and formalin, followed by catalytic hydrogenolysis of the product with palladium-charcoal, N-benzoylation, and oxidation with chromic anhydride.

\section{Relative Configurations of Diastereomeric Reduction Products}

Of the eight pairs of diastereomeric products (IX-XVI), threo-IX, ${ }^{12)}$ erythro-IX, ${ }^{6,12)}$ threo-XIII, ${ }^{13)}$ and erythro-XIII ${ }^{13)}$ are known. Preparations of threo-X, erythro-X, threo-XII, and erythro-XII were performed from known samples as shown in Chart 2 . Thus, the Reformatsky reaction of benzaldehyde with methyl 2-bromopropionate afforded a diastereomeric mixture of methyl 2-methyl-3-phenylhydracrylate (XXI). The reaction of XXI with hydrazine hydrate followed by fractional recrystallizations gave a high-melting isomer (erythro$\mathrm{XXII}$ ) and a low-melting isomer (threo-XXII), whose relative configurations had been demonstrated. ${ }^{14)}$ Hydrolysis of erythro-XXII afforded the corresponding carboxylic acid (erythroXXIII); lithium aluminum hydride reduction of which gave erythro-XII. Esterification of erythro-XXIII followed by a reaction with ammonia in methanol afforded the erythro-amide (erythro-XXV). Lithium aluminum hydride reduction of erythro-XXV afforded erythro-X. On the other hand, threo-X and threo-XII were conveniently obtained from II and IV, respectively. Thus, sodium borohydride reduction of II followed by repeated recrystallizations afforded threo-X. Sodium borohydride reduction of IV followed by a reaction with $p$-nitrobenzoyl chloride in pyridine, then by repeated recrystallizations of the product gave one isomer (threoXXVI) of $\mathrm{mp} 156-157^{\circ}$. Hydrolysis of this afforded threo-XII.

threo-XIV was obtained by lithium aluminum hydride reduction of threo-phenylserine amide. ${ }^{15)}$

In similar reaction sequences, threo-XV, erythro-XV, and erythro-XVI were prepared and their relative configurations were demonstrated with the aid of nuclear magnetic resonance (NMR), as shown in Chart 3. Aldol condensation of benzaldehyde and methyl methoxyacetate was successful only when diethylaminomagnesium bromide was used ${ }^{16)}$ to give a diastereomeric mixture of methyl 2-methoxy-3-methylhydracrylate (XXVII) in $15 \%$ yield. The reaction of XXVII with ammonia in methanol followed by repeated recrystallizations of the product afforded the amide (erythro-XXVIII), from which the corresponding acid (erythro$\mathrm{XXIX)}$, the alcohol (erythro-XV) and the amine (erythro-XVI) were derived. The isomeric alcohol (threo-XV) was obtained from VII as shown in Chart 3. Their relative configurations were demonstrated by converting diastereomeric diols (threo-XV and erythro-XV) to their corresponding 1,3-dioxane derivatives (threo-XXXI and erythro-XXXI, as well as threo-XXXII and erythro-XXXII). In their NMR spectra, signals of benzylic protons (Ha) appeared as doublets. Coupling constants were 2.3 and $2.1 \mathrm{~Hz}$ in the 1,3-dioxane derivatives (threo-XXXI and threo-XXXII, respectively) from one diastereomeric diol (threo-XV), while 9.0 and $8.1 \mathrm{~Hz}$ in the 1,3-dioxane derivatives (erythro-XXXI and erythro-XXXII, respectively) from the other diastereomeric diol (erythro-XV). It is well known that the coupling constant $\left(J_{\mathrm{ab}}\right)$ is decided by the dihedral angle with the adjacent proton $(\mathrm{Hb})$. In six-membered cyclic compounds, values are reported to be $9.2,^{17 a)} 5-8,{ }^{17 b)} 8-14,{ }^{17 c)}$ or $\left.11.0^{17 d}\right) \mathrm{Hz}$ when $\mathrm{Ha}$ and $\mathrm{Hb}$ are

12) W.N. Nagai and S. Kanao, Ann., 470, 157 (1929).

13) K.N.F. Shaw and S.F. Fox, J.Am. Chem. Soc., 75, 3417 (1953).

14) a) H.E. Zimmermann and J. English, Jr., J. Am. Chem. Soc., 76, 2291 (1954); b) J. Wein, Acta Chim. Acad. Sci. Hung., 17, 181 (1958).

15) Pl. A. Plattner, A. Boller, H. Frick, A. Fürst, B. Hegedüs, H. Kirchensteiner, St. Majnoni, R. Schlapfer, and H. Spiegelberg, Helv. Chim. Acta, 40, 1531 (1957).

16) $c f$. K. Sisido, K. Kumazawa, and H. Nozaki, J. Am. Chem. Soc., 82, 125 (1960).

17) a) M. Karplus, J. Chem. Phys., 30, 11 (1959); b) L.M. Jackman, "Applications of Nuclear Magnetic Resonance Spectroscopy in Organic Chemistry," Pergamon Press, New York, N.Y., 1959; c) N.S. Baccha and D.H. Williams, "Application of NMR Spectroscopy. Illustration from the Steroidal Field," Holden-Day Inc., San Francisco, London, Amsterdam, 1964; d) K.C. Ramey and J. Messick, Tetrahedron Letters, 1965, 4423. 


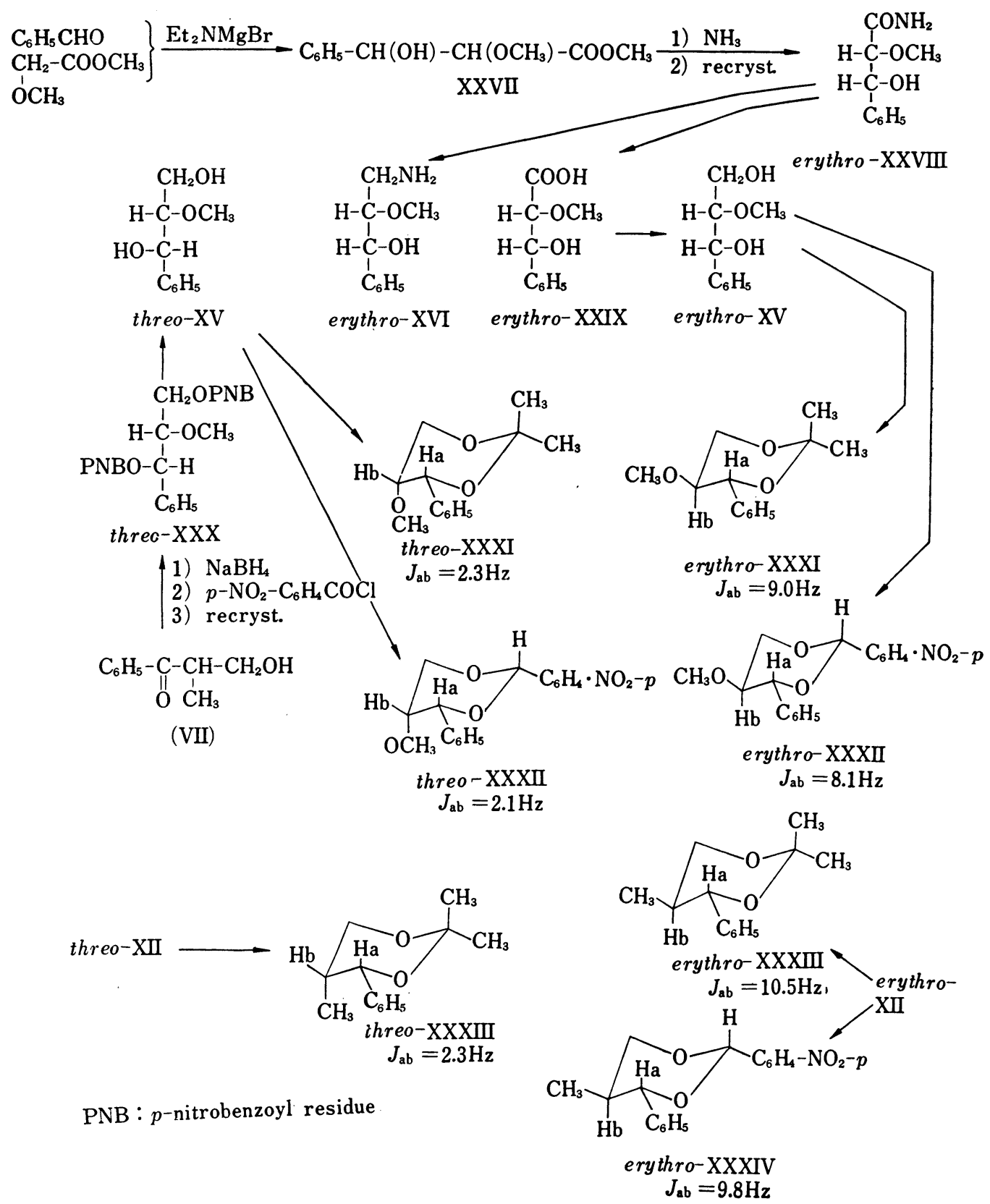

Chart 3. Syntheses and Relative Configurations of XV and XVI

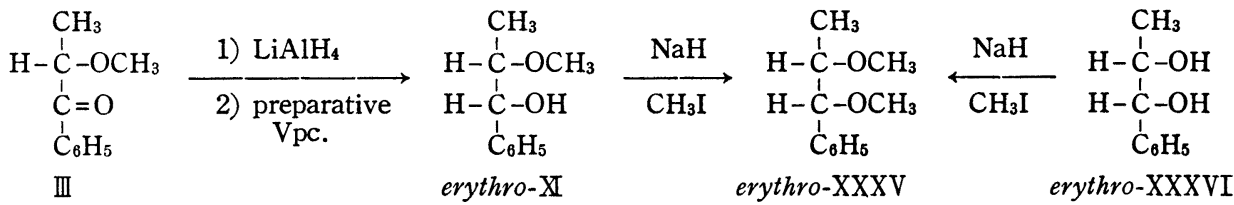

Chart 4. The Isolation and Relative Configuration of erythro-XI 
trans-diaxial $\left(180^{\circ}\right), 1.7,,^{17 a)} 2-4,,^{17 b)} 1-7,{ }^{17 c)}$ or $2.8^{17 d)} \mathrm{Hz}$ when $\mathrm{Ha}$ and $\mathrm{Hb}$ are cis $\left(60^{\circ}\right)$. Values for reference compounds prepared from threo-XII and erythro-XII of known relative configurations, as above, are consistent with reported values. Therefore, the relative configurations of $\mathrm{XV}$ and $\mathrm{XVI}$ were determined, as shown in Chart 3.

Finally the alcohol (erythro-XI) was isolated from a mixture of diastereomers by preparative gas chromatography. Its relative configuration was determined by converting it to the corresponding dimethyl ether derivative (erythro-XXXV), which was identified with an authentic specimen derived from known erythro-1-phenyl-1,2-propanediol (erythro-XXXVI), ${ }^{18)}$ as shown in Chart 4.

\section{Methods for Analyzing the Ratios of Diastereomeric Products}

It was desirable for the present study to be able to analyze the ratios of diastereomers (IX-XVI) produced without purifications or derivative preparations. Therefore, analyses by NMR spectroscopy were initially investigated with various solvents. As a result, acetic acid was found to be the most suitable solvent for the following three reasons; (1) signals of diastereomeric protons at the benzylic position separate well except in XV, (2) products dissolve quite well, and (3) signals of amino- and hydroxy-protons shift away to the carboxyl proton region. Chemical shifts of signals of diastereomeric benzylic protons in the reduction products in acetic acid are shown in Table II. Inspection using synthetic mixture of threo-IX and erythro-IX showed that known and calculated per cent compositions agreed within $2 \%$, when signal areas were analyzed gravimetrically.

TABLE II. A List of Chemical Shifts ( $\tau$-value) of Benzylic Protons in Diastereomers $^{a}$ ) (in $\mathrm{AcOH}, 60 \mathrm{MHz}$ )

\begin{tabular}{lll}
\hline & threo-isomer & erythro-isomer \\
\hline IX & 5.33 & 4.80 \\
X & 4.95 & 5.50 \\
XI & $5.45^{b)}$ & 5.09 \\
XII & 5.05 & 5.50 \\
XIII & $5.16^{c)}$ & $4.86^{c)}$ \\
XIV & 5.00 & $4.58^{b)}$ \\
XV & 5.08 & 5.08 \\
XVI & $5.05^{b)}$ & 5.00 \\
\hline
\end{tabular}

a) for nomenclature, see $7 \mathrm{~b}$;

b) A value obtained from the spectrum of a mixture of diastereomers;

c) A value obtained by the instrument operating at $100 \mathrm{MHz}$.

Analyses of the diastereomeric ratios of XV were performed by gas chromatography after acetylation of the reduction product.

\section{Stereochemical Course of Sodium Borohydride Reduction}

Reduction of the ketones ( 1 mmole) was carried out with sodium borohydride ( 3 mmoles for III, IV, and VII, 4 mmoles for I, II, V, and VIII, 5 mmoles for VI) in ethanol $(20 \mathrm{ml})$ at reflux and ice-cooling $\left(1-4^{\circ}\right)$ temperatures. In ketones I, II, III, and IV, $-\mathrm{NH}_{2} \mathrm{HCl},-\mathrm{OH}$, or $-\mathrm{OCH}_{3}$ groups are attached at $\alpha$ - or $\beta$-position to the carbonyl group. In ketones $\mathrm{V}, \mathrm{VI}$, VII, and VIII, these groups are attached both at $\alpha$ - and $\beta$-positions to the carbonyl group. The direction and degree of 1,2-asymmetric induction were investigated in relation to the neighboring functional groups. Results are shown in Table III, from which the following conclusions were drawn.

It is apparent that the directions of 1,2-asymmetric induction in sodium borohydride reduction of I and III agree with those predicted by a five-membered cyclic model ${ }^{5 d, e, g)}$ with the

18) M. Svoboda and J. Sicher, Collection Czech. Chem. Commun., 20, 1452 (1955). 
TABLE III. Diastereomeric Ratios in Reduction Products

\begin{tabular}{|c|c|c|c|c|c|c|c|}
\hline Compound & $\mathrm{C}_{6} \mathrm{H}_{5}-\mathrm{CO}$ & $\mathrm{Y}$ & $\begin{array}{c}\text { at } \\
\text { threo } \\
(\%)\end{array}$ & $\begin{array}{c}1-4^{\circ} \\
\text { :erythro } \\
(\%)\end{array}$ & $\begin{array}{c}\text { at } \\
\text { threo:e } \\
(\%)\end{array}$ & $\begin{array}{c}78^{\circ} \\
\text { erythro } \\
(\%)\end{array}$ & $\begin{array}{l}\left.\left|\Delta . J \mathrm{~F}^{*}\right| a\right) \\
\mathrm{kcal} / \mathrm{mole}\end{array}$ \\
\hline I & $\mathrm{NH}_{2} \mathrm{HCl}$ & $\mathrm{H}$ & $<5$ & $:>95$ & 8 & : 92 & 1.7 \\
\hline II & $\mathrm{CH}_{3}$ & $\mathrm{NH}_{2} \mathrm{HCl}$ & 94 & $: \quad 6$ & 90 & $: 10$ & 1.5 \\
\hline III & $\mathrm{OCH}_{3}$ & $\mathrm{H}$ & 17 & : $\quad 83$ & 27 & : 73 & 0.7 \\
\hline IV & $\mathrm{CH}_{3}$ & $\mathrm{OH}$ & 77 & : $\quad 23$ & 71 & : 29 & 0.6 \\
\hline $\mathrm{V}$ & $\mathrm{NH}_{2} \mathrm{HCl}$ & $\mathrm{OH}$ & 19 & : 81 & 44 & : 56 & 0.2 \\
\hline VI & $\mathrm{NH}_{2} \mathrm{HCl}$ & $\mathrm{NH}_{2} \mathrm{HCl}$ & 50 & : 50 & 36 & : 64 & 0.4 \\
\hline VII & $\mathrm{OCH}_{3}$ & $\mathrm{OH}$ & 34 & 66 & 41 & : 59 & 0.3 \\
\hline XIII & $\mathrm{OCH}_{3}^{\circ}$ & $\mathrm{NH}_{2} \mathrm{HCl}$ & 2 & $1^{b)}$ & 3 & $: 2^{b)}$ & 0.3 \\
\hline
\end{tabular}

a) Calculated based on data at $78^{\circ}$;

b) rough estimation

participation of a functional group attached at $\alpha$-position to the carbonyl group. In II and IV, reduction products were rich in threo-isomer. This result is explainable by assuming a sixmembered empirical model (XXXVII), with participation of a functional group at $\beta$-position to the carbonyl group. The six-membered model (XXXVII) is, therefore, empirically applicable for predicting the stereochemical course<smiles>[Y]C[C@H](C)[C@H](C)O</smiles>
in the reduction of ketones having a functional group at $\beta$-position to the carbonyl group. ${ }^{4 c, 5 b, f)}$

As to the degree of 1,2 -asymmetric induction, they are far greater in the reduction of I and II than in that of III and IV. Although it is not certain that the influence of one mole of hydrochloric acid in the reduction of I and II is, we believe, from the synthetic point of view, that there is a high degree of 1,2 -asymmetric induction in the sodium borohydride reduction of $\alpha$-amino ketone hydrochloride and $\beta$-amino ketone hydrochloride to the corresponding erythro-isomer and threo-isomer, respectively. Also, the effect of the $-\mathrm{NH}_{2} \mathrm{HCl}$ group on the degree of 1,2 -asymmetric induction is similar whether the group is situated at $\alpha$ - or $\beta$-position to the carbonyl group.

Finally, stereoselectivity is decreased in the reduction of ketones with functional groups both at $\alpha$ - and $\beta$-positions to the carbonyl group. This is a reasonable supposition because the effect of the group at $\alpha$-position on the direction of 1,2 -asymmetric induction is opposite to that at $\beta$-position, which results in cancellation of these effects on each other.

\section{Experimental ${ }^{19)}$}

Materials $-\mathrm{NaBH}_{4}$ was purchased from Kawaken Fine Chemicals Co. Ltd., and its purity was assumed to be $95 \%$. Commercial AcOH of special grade was used as a solvent in determining the ratios of diastereomers by NMR spectroscopy.

19) All melting and boiling points are uncorrected. IR spectra were measured with a Koken DS-402G spectrometer. NMR spectra were measured with a JNM 3H-60 spectrometer operating at $60 \mathrm{MHz}$ or with a Varian A-100 spectrometer operating at $100 \mathrm{MHz}$ using TMS as an internal standard. Analytical gas chromatography was performed with a Shimadzu Gas Chromatograph GC-1B equipped with a hydrogen flame ionization detector. Preparative gas chromatography was performed with the same instrument equipped with an automatic preparative attachment and a thermal conductivity detector. Microanalyses and spectral measurements were performed by the members of the Central Analysis Room of this Faculty. 
2-Aminopropiophenone Hydrochloride (I) - mp $184-185^{\circ}$ (decomp.) (reported ${ }^{8)} \mathrm{mp}^{183}-184^{\circ}$ (decomp.)). IR $\nu_{\max }^{\mathrm{KBr}} \mathrm{cm}^{-1}: 1692(\mathrm{C}=\mathrm{O})$. Anal. Calcd. for $\mathrm{C}_{9} \mathrm{H}_{11} \mathrm{ON} \cdot \mathrm{HCl}: \mathrm{N}, 7.55$. Found: $\mathrm{N}, 7.65$.

2-Methoxypropiophenone (III) — bp $103-105^{\circ}(7 \mathrm{mmHg})$ (reported ${ }^{9)}$ bp $\left.76-77^{\circ}(0.8 \mathrm{mmHg})\right)$. IR $v_{\max }^{119 .} \mathrm{cm}^{-1}: 2805\left(\mathrm{OCH}_{3}\right) .1695(\mathrm{C}=\mathrm{O})$.

Semicarbazone: $\mathrm{mp} 151-153^{\circ}$. Anal. Calcd. for $\mathrm{C}_{11} \mathrm{H}_{15} \mathrm{O}_{2} \mathrm{~N}_{3}: \mathrm{C}, 59.71 ; \mathrm{H}, 6.83 ; \mathrm{N}, 18.99$. Found: C, $59.96 ; \mathrm{H}, 6.91 ; \mathrm{N}, 19.17$.

3-Hydroxy-2-methylpropiophenone (IV)—bp $136-137^{\circ} \quad(3 \mathrm{mmHg}) \quad$ (reported $\left.^{10}\right)$ bp $116-117^{\circ}(1.5-$ $2.0 \mathrm{mmHg})$ ). IR $v_{\max }^{\text {11q. }} \mathrm{cm}^{-1}:-3400(\mathrm{OH}), 1685(\mathrm{C}=\mathrm{O})$.

2,4-Dinitrophenylhydrazone: $\mathrm{mp} 150-152^{\circ}$. Anal. Calcd. for $\mathrm{C}_{16} \mathrm{H}_{16} \mathrm{O}_{5} \mathrm{~N}_{4}: \mathrm{C}, 55.81 ; \mathrm{H}, 4.68 ; \mathrm{N}$, 16.27. Found: C, 55.82; H, 4.52; N, 16.12 .

2-Amino-3-hydroxypropiophenone Hydrochloride $(\mathrm{V})-\mathrm{mp} 164-165^{\circ}$ (decomp.) (reported ${ }^{11)} \mathrm{mp}^{164^{\circ}}$ ). IR $v_{\max }^{\mathrm{KBr}} \mathrm{cm}^{-1}: 1700(\mathrm{C}=\mathrm{O})$. Anal. Calcd. for $\mathrm{C}_{9} \mathrm{H}_{11} \mathrm{O}_{2} \mathrm{~N} \cdot \mathrm{HCl}: \mathrm{N}, 6.95$. Found: $\mathrm{N}, 6.90$.

$\mathbf{N}$ (2-Methyl-3-oxo-3-phenylpropyl)phthalimide (XVII) - $\mathrm{SOCl}_{2}(7.8 \mathrm{~g}, 65.6 \mathrm{mmoles})$ was added to a solution of IV $(7.0 \mathrm{~g}, 43.7 \mathrm{mmoles})$ in benzene $(50 \mathrm{ml})$ under stirring and the whole was allowed to stand at room temperature overnight. After evaporation to dryness, the residue was heated with phthalimide $(6.5 \mathrm{~g}, 44 \mathrm{mmoles})$ and $\mathrm{K}_{2} \mathrm{CO}_{3}(3.1 \mathrm{~g}, 22 \mathrm{mmoles})$ at $180-200^{\circ}$ for $3 \mathrm{hr}$. The reaction mixture was taken up in $\mathrm{CHCl}_{3}$, washed with $10 \%$ aq. $\mathrm{NaOH}, 10 \%$ aq. $\mathrm{HCl}, \mathrm{H}_{2} \mathrm{O}$, and dried over anhyd. $\mathrm{Na}_{2} \mathrm{SO}_{4}$. Evaporation of the $\mathrm{CHCl}_{3}$ gave a solid, which was recrystallized from benzene-hexane to colorless prisms of XVII (7.3 g, $57 \%$ yield), mp 74-76.5 . IR $\nu_{\max }^{\mathrm{KBr}} \mathrm{cm}^{-1}: 1772,1717$ (phthalimide), $1678(\mathrm{C}=\mathrm{O})$. Anal. Calcd. for $\mathrm{C}_{18} \mathrm{H}_{15}-$ $\mathrm{O}_{3} \mathrm{~N}: \mathrm{N}, 4.78$. Found: $\mathrm{N}, 4.62$.

3-Amino-2-methylpropiophenone Hydrochloride (II)_-A solution of XVII (7.0 g) in AcOH (70 ml) and conc. $\mathrm{HCl}(50 \mathrm{ml})$ was refluxed for $8 \mathrm{hr}$, then evaporated to dryness. The residue was taken up in cold $\mathrm{H}_{2} \mathrm{O}$ (ca. $100 \mathrm{ml}$ ), after which insoluble materials were filtered off and the filtrate evaporated to dryness in vacuo. The residue was recrystallized from EtOH-ether to the colorless powder of II $(2.1 \mathrm{~g}, 44 \%$ yield), $\mathrm{mp} 122-123.5^{\circ}$. IR $\nu_{\max }^{\mathrm{KBr}} \mathrm{cm}^{-1}: 1677(\mathrm{C}=\mathrm{O})$. Anal. Calcd. for $\mathrm{C}_{10} \mathrm{H}_{13} \mathrm{ON} \cdot \mathrm{HCl}: \mathrm{C}, 60.15 ; \mathrm{H}, 7.07$; $\mathrm{N}, 7.02$. Found: $\mathrm{C}, 60.23 ; \mathrm{H}, 6.86 ; \mathrm{N}, 7.23$.

2,3-Diaminopropiophenone Dihydrochloride (VI) - $\mathrm{N}$ (3-Oxo-3-phenyl-2-phthalimidopropyl)phthalimide

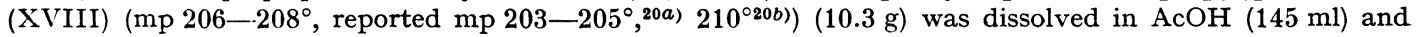
conc. $\mathrm{HCl}(66 \mathrm{ml})$, and the whole was refluxed for $10 \mathrm{hr}$. The reaction mixture was evaporated in vacuo to dryness, after which the residue was dissolved again in $\mathrm{AcOH}(145 \mathrm{ml})$ and conc. $\mathrm{HCl}(66 \mathrm{ml})$. The solution was refluxed for $3 \mathrm{hr}$, then evaporated to dryness in vacuo. $10 \%$ aq. $\mathrm{HCl}(150 \mathrm{ml})$ and $\mathrm{H}_{2} \mathrm{O}(80 \mathrm{ml})$ were added to the residue, and the insoluble materials were filtered off. The filtrate was washed with Ac$\mathrm{OEt}$ and benzene. The aqueous layer was treated with charcoal and filtered. The filtrate was evaporated to dryness in vacuo to give a solid, which was recrystallized from MeOH-ether to colorless leaflets of VI (1.9 g, 33\% yield), mp 221-221.5 (decomp.). IR $\nu_{\max }^{\mathrm{KBr}} \mathrm{cm}^{-1}: 1705 \quad(\mathrm{C}=\mathrm{O})$. Anal. Calcd. for $\mathrm{C}_{9} \mathrm{H}_{12} \mathrm{ON}_{2}$. $2 \mathrm{HCl}$ : C, 45.58; H, 5.95; N, 11.81. Found: C, 45.43; H, 6.17; N, 11.93.

3-Hydroxy-2-methoxypropiophenone (VII) — A suspension of 2-methoxyacetophenone (XIX) (bp 116$\left.119^{\circ}(15 \mathrm{mmHg})\right)(6.5 \mathrm{~g}, 43 \mathrm{mmoles})$, paraformaldehyde $(2.6 \mathrm{~g}, 86 \mathrm{mmoles}), \mathrm{MeOH}(100 \mathrm{ml}), \mathrm{H}_{2} \mathrm{O}(50 \mathrm{ml})$, and $\mathrm{Ca}(\mathrm{OH})_{2}(150 \mathrm{mg}, 2 \mathrm{mmoles})$ was refluxed for $30 \mathrm{~min}$. The reaction mixture became a clear solution. $\mathrm{Na}_{2} \mathrm{SO}_{3}(5.4 \mathrm{~g}, 43 \mathrm{mmoles})$ was added to the solution and then the solution was made acidic with $10 \%$ aq. $\mathrm{H}_{2} \mathrm{SO}_{4}$. The reaction mixture was concentrated to about one-third of its volume under reduced pressure, and extracted with $\mathrm{CHCl}_{3}$. Dried $\mathrm{CHCl}_{3}$ extracts were evaporated, in vacuo to dryness, and the residual oil $(6.5 \mathrm{~g})$ was chromatographed on silica gel $(130 \mathrm{~g})$ with $2.5 \% \mathrm{EtOH}-\mathrm{CHCl}_{3}$ to give colorless oil of VII $\left(3.1 \mathrm{~g}, 40 \%\right.$ yield). IR $v_{\max }^{11 \mathrm{lq} .} \mathrm{cm}^{-1}: 3400(\mathrm{OH}), 2830\left(\mathrm{OCH}_{3}\right), 1690(\mathrm{C}=\mathrm{O})$.

2,4-Dinitrophenylhydrazone: $\mathrm{mp} 195-196^{\circ}$. Anal. Calcd. for $\mathrm{C}_{16} \mathrm{H}_{16} \mathrm{O}_{3} \mathrm{~N}_{4}: \mathrm{C}, 53.33 ; \mathrm{H}, 4.48 ; \mathrm{N}, 15.55$. Found: C, $53.04 ; \mathrm{H}, 4.41 ; \mathrm{N}, 15.59$.

N(2-Methoxy-3-oxo-3-phenylpropyl) benzamide (XX)—A mixture of XIX (18.6 g, $124 \mathrm{mmoles})$, benzylamine hydrochloride $(17.8 \mathrm{~g}, 124 \mathrm{mmoles})$ and $35 \%$ aq. formalin $(12.6 \mathrm{ml})$ was heated on a water-bath for $1.5 \mathrm{hr}$. The reddish brown reaction mixture was evaporated to dryness under reduced pressure. The residue was mixed with $\mathrm{H}_{2} \mathrm{O}(c a .500 \mathrm{ml})$ and the whole was washed with ether. The aqueous layer was made alkaline with $\mathrm{K}_{2} \mathrm{CO}_{3}$, and extracted with benzene. The benzene solution was washed with $\mathrm{H}_{2} \mathrm{O}$, and extracted with $10 \%$ aq. $\mathrm{HCl}$. Evaporation of the aqueous $\mathrm{HCl}$ solution in vacuo to dryness afforded a. yellowish-brown viscous oil $(14.0 \mathrm{~g})$. The oil was dissolved in EtOH $(130 \mathrm{ml})$ and hydrogenated at the atmospheric pressure of $\mathrm{H}_{2}$ with $5 \%$ Pd-C (4 g) until $1485 \mathrm{ml}$ of $\mathrm{H}_{2}$ was absorbed. The catalyst was filtered. off and the filtrate was evaporated to dryness in vacuo. The residue was dissolved in $\mathrm{H}_{2} \mathrm{O}$, after which some insoluble materials were filtered off, then the filtrate was made alkaline with $\mathrm{K}_{2} \mathrm{CO}_{3}$. Extraction with ether followed by evaporation of the dried ether solution afforded a viscous oily residue, which was: mixed with benzoyl chloride $(14.1 \mathrm{~g}, 100 \mathrm{mmoles})$ in pyridine $(100 \mathrm{ml})$ and the whole was allowed to stand at room temperature overnight. From the usual work up, a neutral fraction was obtained as a viscous oil

20) a) M.C. Rebstock, J. Org. Chem., 19, 851 (1954); b) K. Yee-sheng, P. Pei-chuan, L. Sheun-hsing, C. Chi-hao, and H. Hsiu-yung, Scientia Sinica, 7, 738 (1958). 
(15.1 g). This was dissolved in a solution of $\mathrm{NaOH}(2.0 \mathrm{~g})$ in $\mathrm{MeOH}(200 \mathrm{ml})$, and the whole was refluxed for $1.5 \mathrm{hr}$. Evaporation of the solvent to dryness in vacuo gave a residue, which was taken up in $\mathrm{CHCl}_{3}$. The $\mathrm{CHCl}_{3}$ suspension was washed with $10 \%$ aq. $\mathrm{HCl}, 10 \%$ aq. $\mathrm{NaOH}, \mathrm{H}_{2} \mathrm{O}$, dried, and evaporated to give an oil $(\mathbf{1 0 . 5} \mathrm{g})$, which was dissolved in $\mathrm{AcOH}(30 \mathrm{ml})$. Under ice-cooling, a solution of $\mathrm{CrO}_{3}(3.72 \mathrm{~g}, 37.2$ mmoles) in $\mathrm{AcOH}(15 \mathrm{ml})$ and $\mathrm{H}_{2} \mathrm{O}(5 \mathrm{ml})$ was added, and the whole was allowed to stand for $4 \mathrm{hr}$ under icecooling. The reaction mixture was poured into ice-water, and extracted with $\mathrm{CHCl}_{3}$. The $\mathrm{CHCl}_{3}$ extracts were washed with $10 \%$ aq. $\mathrm{NaOH}, \mathrm{H}_{2} \mathrm{O}$ and dried. Evaporation of the $\mathrm{CHCl}_{3}$ in vacuo gave an oil (7.9 g) which became semi-solid on scratching. Recrystallization from AcOEt-hexane afforded crude XX (4.3 g, $12 \%$ yield) of $\mathrm{mp} 111-114^{\circ}$. Recrystallizations from benzene-hexane raised the $\mathrm{mp}$ to $118-119^{\circ}$ of colorless fine needles. IR $v_{\max }^{\mathrm{KBr}} \mathrm{cm}^{-1}: 3380(\mathrm{NH}), 1688(\mathrm{C}=\mathrm{O}), 1646,1532$ (amide). Anal. Calcd. for $\mathrm{C}_{17} \mathrm{H}_{17} \mathrm{O}_{3} \mathrm{~N}$ : C, $72.06 ; \mathrm{H}, 6.05 ; \mathrm{N}, 4.94$. Found: $\mathrm{C}, 72.27 ; \mathrm{H}, 6.01 ; \mathrm{N}, 5.01$.

3-Amino-2-methoxypropiophenone Hydrochloride (VIII)_-A mixture of XX (3.54 g) and ca. 18\% aq. $\mathrm{HCl}(50 \mathrm{ml})$ was refluxed for $6 \mathrm{hr}$. After cool, the reaction mixture was washed with ether, then was evaporated in vacuo to dryness to give a solid. Recrystallization of this solid from EtOH-isopropyl ether afforded crude VIII (940 mg, $35 \%$ yield) of $\mathrm{mp}-113^{\circ}$. Recrystallizations from the same solvent system raised the $\mathrm{mp}$ to $118^{\circ}$. IR $v_{\max }^{\mathrm{KBr}} \mathrm{cm}^{-1}: 1695(\mathrm{C}=\mathrm{O})$. Anal. Calcd. for $\mathrm{C}_{10} \mathrm{H}_{13} \mathrm{O}_{2} \mathrm{~N} \cdot \mathrm{HCl}: \mathrm{C}, 55.69 ; \mathrm{H}, 6.54 ; \mathrm{N}, 6.49$. Found: C, $55.69 ; \mathrm{H}, 6.42 ; \mathrm{N}, 6.47$.

threo-2-Amino-1-phenyl-1-propanol (DL-Norpseudoephedrire) (threo-IX) - mp 75.5-76.5 ${ }^{\circ}$ (reported $\operatorname{mp} 71^{\circ}{ }^{12}$ ) 76.8-77.5 ${ }^{\circ 14 a}$ ) ). NMR (in $\mathrm{AcOH}, 60 \mathrm{MHz}$ ) $\tau: 8.90\left(3 \mathrm{H}\right.$, doublet, $\left.J=6.8 \mathrm{~Hz}, \mathrm{CH}_{3}-\mathrm{CH}_{-}\right)$, $\sim 6.4$ $\left(1 \mathrm{H}\right.$, multiplet, $\left.\mathrm{CH}_{3}-\mathrm{CH}\left(\mathrm{NH}_{2}\right)-\mathrm{CH}-\right), 5.33\left(1 \mathrm{H}\right.$, doublet, $\left.J=9.7 \mathrm{~Hz}, \mathrm{C}_{6} \mathrm{H}_{5}-\mathrm{CH}(\mathrm{OH})-\mathrm{CH}-\right), 2.68$ ( $5 \mathrm{H}$, singlet, $\left.\mathrm{C}_{6} \mathrm{H}_{5}-\right)$. Anal. Calcd. for $\mathrm{C}_{9} \mathrm{H}_{13} \mathrm{ON}: \mathrm{N}, 9.26$. Found: $\mathrm{N}, 9.04$.

erythro-2-Amino-1-phenyl-1-propanol (DL-Norephedrine) (erythro-IX) — mp 100-101.5 (reported $\mathrm{mp}$ $\left.100-101.5^{\circ 6}\right)$ ). NMR (in $\left.\mathrm{AcCH}, 60 \mathrm{MHz}\right) \tau: 8.90\left(3 \mathrm{H}\right.$, doublet, $J=6.3 \mathrm{~Hz}, \mathrm{CH}_{3}-\mathrm{CH}-$ ), -6.3 (1 $\mathrm{H}$, multiplet, $\left.\mathrm{CH}_{3}-\mathrm{CH}\left(\mathrm{NH}_{2}\right)-\mathrm{CH}-\right), 4.80\left(1 \mathrm{H}\right.$, doublet, $\left.J=2.4 \mathrm{~Hz}, \mathrm{C}_{6} \mathrm{H}_{5}-\mathrm{CH}(\mathrm{OH})-\mathrm{CH}-\right), 2.67\left(5 \mathrm{H}\right.$, singlet, $\left.\mathrm{C}_{6} \underline{\mathrm{H}}_{5}-\right)$. Anal. Calcd. for $\mathrm{C}_{9} \mathrm{H}_{13} \mathrm{ON}: \mathrm{N}, 9.26$. Found: $\mathrm{N}, 9.30$.

threo-2-Amino-1-phenyl-1,3-propanediol(threo-XIII)__-threo-Phenylserine ethyl ester hydrochloride ( $\mathrm{mp}$ $138-139.5^{\circ}$, reported ${ }^{13}$ ) $\mathrm{mp} 140^{\circ}$ ) was reduced with $\mathrm{NaBH}_{4}{ }^{21)}$ to threo-XIII of mp $87-89^{\circ}$ (reported ${ }^{13}$ ) mp $88-89^{\circ}$ ). NMR (in $\left.\mathrm{AcOH}, 100 \mathrm{MHz}\right) \tau: 5.16\left(1 \mathrm{H}, \mathrm{C}_{6} \mathrm{H}_{5}-\mathrm{CH}(\mathrm{OH})-\mathrm{CH}-\right.$ ). Anal. Calcd. for $\mathrm{C}_{9} \mathrm{H}_{13} \mathrm{O}_{2} \mathrm{~N}: \mathrm{N}_{\text {, }}$ 8.38. Found: $\mathrm{N}, \mathbf{8 . 5 0}$.

erythro-2-Amino-1-phenyl-1,3-propanediol (erythro-XIII)—erythro-Phenylserine ethyl ester hydrochloride (mp $175.5-176^{\circ}$ (decomp.), reported ${ }^{13)} \mathrm{mp} 175-176^{\circ}$ (decomp.)) was reduced with $\mathrm{NaBH}_{4}{ }^{21)}$ to erythro-

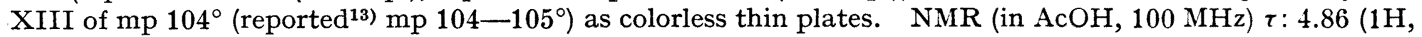
$\left.\mathrm{C}_{6} \mathrm{H}_{5}-\mathrm{CH}(\mathrm{OH})-\mathrm{CH}-\right)$. Anal. Calcd. for $\mathrm{C}_{9} \mathrm{H}_{13} \mathrm{O}_{2} \mathrm{~N}: \mathrm{N}, 8.38$. Found: N, 8.50.

erythro-2-Methyl-3-phenylhydracrylic Acid Hydrazide(erythro-XXII)—A diastereomeric mixture of methyl 2-methyl-3-phenylhydracrylate (XXI) $(32.5 \mathrm{~g}, 0.167$ mole) prepared according to the reported method ${ }^{14)}$ was mixed with hydrazine hydrate $(19.5 \mathrm{~g}, 0.488 \mathrm{~mole})$ at room temperature, and the whole was agitated until it solidified. After standing at room temperature for 2 days, the whole was recrystallized from $140 \mathrm{ml}$ of $\mathrm{H}_{2} \mathrm{O}$. The deposited crystals were recrystallized from EtOH to afford colorless needles of erythro-XXII $\left(11.6 \mathrm{~g}, 36 \%\right.$ yield) of mp 194-195 (reported $^{14 b}$ ) mp 196 $)$. IR $v_{\max }^{\mathrm{KBr}} \mathrm{cm}^{-1}: 1633,1538$ (hydrazide). Anal. Calcd. for $\mathrm{C}_{10} \mathrm{H}_{14} \mathrm{O}_{2} \mathrm{~N}_{2}: \mathrm{N}, 14.42$; Found: N, 14.70 .

By evaporating the above aqueous mother liquor to dryness, followed by recrystallizing the residue twice from EtOH, the corresponding threo-XXII (10.6 g, 33\% yield) was obtained as colorless fine needles of $\operatorname{mp} 138-139^{\circ}$.

erythro-2-Methyl-3-phenylhydracrylic Acid (erythro-XIII)—A mixture of erythro-XXII (1.0 g) in $20 \%$ aq. $\mathrm{KOH}(30 \mathrm{ml})$ and EtOH $(10 \mathrm{ml})$ was refluxed for three and one-third $\mathrm{hr}$. After cool, the reaction mixture was brought to $\mathrm{pH} 1$ with conc. $\mathrm{HCl}$, and the whole was extracted with ether. On evaporation of the dried ethereal extracts, a pale brown solid was obtained. Recrystallizations of this solid from benzenehexane followed by recrystallization from AcOEt-hexane afforded colorless prisms of erythro-XXIII (640 mg, $69 \%$ yield) of $\mathrm{mp} 94.5-95.5^{\circ}$ (reported ${ }^{14 a}$ ) mp 96.5-97.5 ${ }^{\circ}$. Anal. Calcd. for $\mathrm{C}_{10} \mathrm{H}_{12} \mathrm{O}_{3}: \mathrm{C}, 66.65 ; \mathrm{H}, 6.71$. Found: C, $66.75 ; \mathrm{H}, 6.66$.

Methyl erythro-2-Methyl-3-phenylhydracrylate (erythro-XXIV)—a) A diastereomeric mixture of methyl 2-methyl-3-phenylhydracrylate (XXI) (3.0 g) was dissolved in hexane $(300 \mathrm{ml})$ at room temperature, and the solution was cooled to $-20^{\circ}$. Colorless fine needles of erythro-XXIV (420 mg, $14 \%$ yield) were obtained and identified with the specimen obtained in $\mathrm{b}$ ).

b) erythro-XXIV was prepared from erythro-XXIII according to the reported method, ${ }^{14 a)} \mathrm{mp} 49.5$ -

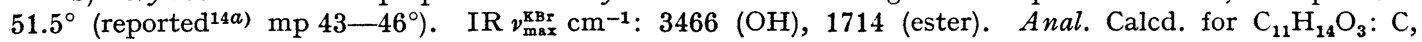
68.03; H, 7.27. Found: C, 68.24; H, 7.11.

erythro-2-Methyl-3-phenylhydracrylamide(erythro-XXV)—a) A solution of erythro-XXIV (420 mg) in $18 \% \mathrm{NH}_{3}$ in $\mathrm{MeOH}(25 \mathrm{ml})$ was sealed tightly and allowed to stand at about $35^{\circ}$ for 4 days. After evaporating to dryness in vacuo, the residue was recrystallized from AcOEt-hexane to afford colorless prisms of

21) H. Seki, K. Koga, H. Matsuo, S. Ohki, I. Matsuo, and S. Yamada, Chem. Pharm. Bull. (Tokyo), 13, 995 (1965). 
erythro-XXV (320 mg, 82\% yield) of $\mathrm{mp} 133.5-135^{\circ}$. IR $\nu_{\max }^{\mathrm{KBr}} \mathrm{cm}^{-1}: 3350,3175(\mathrm{OH}$ and $\mathrm{NH}), 1675,1617$ (amide). Anal. Calcd. for $\mathrm{C}_{10} \mathrm{H}_{13} \mathrm{O}_{2} \mathrm{~N}: \mathrm{C}, 67.02 ; \mathrm{H}, 7.31 ; \mathrm{N}, 7.82$. Found: $\mathrm{C}, 66.97 ; \mathrm{H}, 7.17 ; \mathrm{N}, 7.83$.

b) A mixture of diastereomers of methyl 2-methyl-3-phenylhydracrylate (XXI) (910 mg) was treated as in a), and the crude product was recrystallized from EtOH $(5 \mathrm{ml})$ to give colorless prisms of erythro-XXV (140 mg, $17 \%$ yield), $\mathrm{mp} 133-134.5^{\circ}$. This sample was shown to be identical with the sample prepared in a) by IR and mixed mp test.

erythro-3-Amino-2-methyl-1-phenyl-1-propanol (erythro-X)—_ A solution of erythro-XXV (200 mg, $1.12 \mathrm{mmoles})$ in THF $(20 \mathrm{ml})$ was added dropwise to a suspension of $\mathrm{LiAlH}_{4}(220 \mathrm{mg}, 5.6 \mathrm{mmoles})$ in THF $(30 \mathrm{ml})$, and the whole was refluxed for $5 \mathrm{hr}$. A mixture of $10 \%$ aq. $\mathrm{NaOH}(0.37 \mathrm{ml})$ and $\mathrm{H}_{2} \mathrm{O}(0.63 \mathrm{ml})$ was added to the reaction mixture. Deposited precipitates were filtered off, and washed with a small amount of THF. The combined filtrate and washings were evaporated to dryness in vacuo, and the residue was dissolved in $10 \%$ aq. $\mathrm{HCl}$. This aqueous solution was washed with ether, then evaporated to dryness in vacuo. The residue was taken up in $\mathrm{CHCl}_{3}$, and $\mathrm{CHCl}_{3}$ saturated with $\mathrm{NH}_{3}$ was added in excess after which the deposited precipitates were filtered off. Evaporation of the filtrate in vacuo left the colorless oil of erythro-X (170 mg, 92\% yield). NMR (in $\mathrm{AcOH}, 60 \mathrm{MHz}$ ) $\tau: 9.26$ (3H, doublet, $J=6.8 \mathrm{~Hz}, \mathrm{CH}_{3}-\mathrm{CH}_{-}$), $5.50\left(1 \mathrm{H}\right.$, doublet, $\left.J=8.6 \mathrm{~Hz}, \mathrm{C}_{6} \mathrm{H}_{5}-\mathrm{CH}(\mathrm{OH})-\mathrm{CH}-\right), 2.71\left(5 \mathrm{H}\right.$, singlet, $\left.\mathrm{C}_{6} \mathrm{H}_{5}-\right)$.

erythro-5-Methyl-6-phenyl-1,3-oxazin-2-one: A mixture of erythro-X (830 $\mathrm{mg}, 5 \mathrm{mmoles})$ in benzene $(30 \mathrm{ml}), 10 \%$ aq. $\mathrm{KOH}(13 \mathrm{ml})$ and $24 \%(\mathrm{w} / \mathrm{w}) \mathrm{COCl}_{2}$ in toluene $(7.0 \mathrm{ml})$ was shaken vigorously for $30 \mathrm{~min}$. The organic layer was washed with $\mathrm{H}_{2} \mathrm{O}$, dried over anhyd. $\mathrm{Na}_{2} \mathrm{SO}_{4}$, and evaporated to dryness under reduced pressure. The residue was recrystallized from benzene-hexane to erythro-5-methyl-6-phenyl-1,3-oxazin-2one $\left(690 \mathrm{mg}, 72 \%\right.$ yield) of $\mathrm{mp} 152-157^{\circ}$. Further recrystallization from the same solvent raised the $\mathrm{mp}$ to $157-159^{\circ}$. IR $\nu_{\max }^{\mathrm{KBr}} \mathrm{cm}^{-1}: 3260(\mathrm{NH}), 1700(\mathrm{C}=\mathrm{O})$. $\mathrm{NMR}$ (in $\left.\mathrm{CDCl}_{3}, 60 \mathrm{MHz}\right) \tau: 9.20(3 \mathrm{H}$, doublet, $\left.J=6.8 \mathrm{~Hz}, \mathrm{CH}_{3}-\mathrm{CH}-\right), 5.15\left(1 \mathrm{H}\right.$, doublet, $\left.J=10.1 \mathrm{~Hz}, \mathrm{C}_{6} \mathrm{H}_{5}-\mathrm{CH}(\mathrm{O}-)-\mathrm{CH}-\right), 2.66$ (5H, singlet, $\left.\mathrm{C}_{6} \mathrm{H}_{5}-\right)$. Anal. Calcd. for $\mathrm{C}_{11} \mathrm{H}_{13} \mathrm{O}_{2} \mathrm{~N}: \mathrm{C}, 69.09 ; \mathrm{H}, 6.85 ; \mathrm{N}, 7.33$. Found: $\mathrm{C}, 69.20 ; \mathrm{H}, 7.15 ; \mathrm{N}, 7.46$.

threo-3-Amino-2-methyl-1-phenyl-1-propanol (threo-X)—A mixture of II (1.9 g, $10 \mathrm{mmoles})$ and $\mathrm{NaBH}_{4}(600 \mathrm{mg}, 15 \mathrm{mmoles})$ in EtOH $(60 \mathrm{ml})$ was allowed to stand at room temperature overnight. The reaction mixture was brought to $\mathrm{pH} 3$ with $10 \%$ aq. $\mathrm{HCl}$. Deposited precipitates were filtered off, and the filtrate was evaporated to dryness. The residue was taken up in $\mathrm{CHCl}_{3}$ and $\mathrm{CHCl}_{3}$ saturated with $\mathrm{NH}_{3}$ was added in excess. Deposited precipitates were filtered off, and the filtrate was evaporated to dryness in vacuo to give a solid. The solid was recrystallized twice from isopropyl ether, three times from benzenehexane to afford colorless needles of threo-X $\left(260 \mathrm{mg}, 13 \%\right.$ yield) of mp 93-94. ${ }^{\circ}$. NMR (in AcOH, $60 \mathrm{MHz}$ ) $\tau$ : $9.17\left(3 \mathrm{H}\right.$, doublet, $\left.J=6.8 \mathrm{~Hz}, \mathrm{CH}_{3}-\mathrm{CH}-\right), 4.95$ (1H, doublet, $\left.J=3.8 \mathrm{~Hz}, \mathrm{C}_{6} \mathrm{H}_{5}-\mathrm{CH}(\mathrm{OH})-\mathrm{CH}-\right), 2.61(5 \mathrm{H}$, singlet, $\mathrm{C}_{6} \mathrm{H}_{5^{-}}$). Anal. Calcd. for $\mathrm{C}_{10} \mathrm{H}_{15} \mathrm{ON}: \mathrm{C}, 72.69 ; \mathrm{H}, 9.15 ; \mathrm{N}, 8.48$. Found: $\mathrm{C}, 72.57 ; \mathrm{H}, 9.15 ; \mathrm{N}, 8.52$.

erythro-2-Methyl-1-phenyl-1,3-propanediol (erythro-XII) - A suspension of erythro-XXIII (950 mg, $5.3 \mathrm{mmoles})$ and $\mathrm{LiAlH}_{4}(640 \mathrm{mg}, 16 \mathrm{mmoles})$ in THF $(100 \mathrm{ml})$ was refluxed for $3 \mathrm{hr}$ and the whole was allowed to stand at room temperature overnight. A solution of $10 \%$ aq. $\mathrm{NaOH}(1.0 \mathrm{ml})$ and $\mathrm{H}_{2} \mathrm{O}(1.6 \mathrm{ml})$ was added to the reaction mixture, and the deposited precipitates were filtered off. Evaporation of the filtrate in vacuo afforded an oily residue, which was chromatographed on alumina (100 g) with $\mathrm{CHCl}_{3}-$ benzene (95: 5) to give erythro-XII (700 mg, $80 \%$ yield) as a colorless liquid. NMR (in AcOH, $60 \mathrm{MHz}) \tau: 9.34(3 \mathrm{H}$, doublet, $\left.J=6.8 \mathrm{~Hz}, \mathrm{CH}_{3}-\mathrm{CH}-\right), 5.50\left(1 \mathrm{H}\right.$, doublet, $\left.J=7.5 \mathrm{~Hz}, \mathrm{C}_{6} \mathrm{H}_{5}-\mathrm{CH}(\mathrm{OH})-\mathrm{CH}-\right), 2.68\left(5 \mathrm{H}\right.$, singlet, $\left.\mathrm{C}_{6} \mathrm{H}_{5}-\right)$. erythro-2,2,5-Trimethyl-4-phenyl-1,3-dioxane (erythro-XXXIII): A mixture of erythro-XII (300 mg), anhyd. $\mathrm{CuSO}_{4}(1.0 \mathrm{~g})$ and dehyd. acetone $(20 \mathrm{ml})$ was stirred at room temperature for 4 days. Insoluble materials were filtered off, and washed with a small amount of acetone. The filtrate and the washings were combined and evaporated to dryness in vacuo. The oily residue was chromatographed on silica gel (32 g) with AcOEt-benzene (1:2) to give erythro-XXXIII $\left(230 \mathrm{mg}, 54 \%\right.$ yield) as a colorless oil, bp $150-152^{\circ}$ (30 mmHg). NMR (in $\left.\mathrm{CCl}_{4}, 60 \mathrm{MHz}\right) \tau: 9.42\left(3 \mathrm{H}\right.$, doublet, $\left.J=7.1 \mathrm{~Hz}, \mathrm{CH}_{3}-\mathrm{CH}-\right), 8.61\left(3 \mathrm{H}\right.$, singlet, $\left.\mathrm{CH}_{3}-\mathrm{C}\right)$, $8.53\left(3 \mathrm{H}\right.$, singlet, $\left.\mathrm{CH}_{3}-\mathrm{C}\right),-8.1\left(1 \mathrm{H}\right.$, multiplet, $\left.\mathrm{CH}_{3}-\mathrm{CH}\left(\mathrm{CH}_{2^{-}}\right)-\mathrm{CH}-\right), 5.70\left(1 \mathrm{H}\right.$, doublet, $J=10.5 \mathrm{~Hz}, \mathrm{C}_{6} \mathrm{H}_{5}^{-}$ $\mathrm{CH}(\mathrm{O}-)-\mathrm{CH}-), 2.67\left(5 \mathrm{H}\right.$, singlet, $\left.\mathrm{C}_{6} \mathrm{H}_{5^{-}}\right)$. Anal. Calcd. for $\mathrm{C}_{13} \mathrm{H}_{18} \mathrm{O}_{2}: \mathrm{C}, 75.69 ; \mathrm{H}, 8.80$. Found: $\mathrm{C}, 75.72$; $\mathrm{H}, 8.81$.

erythro-5-Methyl-2-(p-nitrophenyl)-4-phenyl-1,3-dioxane (erythro-XXXIV): A solution of erythro-XII (700 mg, $4.2 \mathrm{mmoles})$, $p$-nitrobenzaldehyde $\left(750 \mathrm{mg}, 5 \mathrm{mmoles}\right.$ ) and conc. $\mathrm{H}_{2} \mathrm{SO}_{4}$ (1 drop) in dehyd. xylene $(50 \mathrm{ml})$ was evaporated to dryness in vacuo under water bath heating. Dehyd. xylene $(50 \mathrm{ml})$ was added to the residue again, and the whole was evaporated in the same manner. The residue was taken up in benzene, washed with aq. $\mathrm{NaHSO}_{3}, \mathrm{H}_{2} \mathrm{O}$, and dried over anhyd. $\mathrm{Na}_{2} \mathrm{SO}_{4}$. Evaporation of the benzene in vacuo afforded a solid, which was recrystallized from benzene-hexane to give pale yellow prisms of erythroXXXIV $\left(760 \mathrm{mg}, 60 \%\right.$ yield) of mp $120-123^{\circ}$. Two recrystallizations from the same solvent system raised the $\mathrm{mp}$ to $122-123^{\circ}$. NMR (in $\mathrm{CDCl}_{3}, 60 \mathrm{MHz}$ ) $\tau: 9.32\left(3 \mathrm{H}\right.$, doublet, $J=6.8 \mathrm{~Hz}, \mathrm{CH}_{3}-\mathrm{CH}-$ ), $7.6-8.2$ (1H, multiplet, $\left.\mathrm{CH}_{3}-\mathrm{CH}\left(\mathrm{CH}_{2}-\right)-\mathrm{CH}-\right)$, 6.30 (1H, triplet, $\left.J=10.8 \mathrm{~Hz},-\mathrm{O}-\mathrm{CH}_{2}-\mathrm{CH}-\right)$, 5.70 (1H, doublet-doublet, $J=10.8$ and $\left.4.5 \mathrm{~Hz},-\mathrm{O}-\mathrm{CH}_{2}-\mathrm{CH}-\right), 5.58\left(1 \mathrm{H}\right.$, doublet, $\left.J=9.8 \mathrm{~Hz}, \mathrm{C}_{6} \mathrm{H}_{5}-\mathrm{CH}(\mathrm{O}-)-\mathrm{CH}-\right), 4.26(1 \mathrm{H}$, singlet, -O-CH $\left.\left(\mathrm{C}_{6} \mathrm{H}_{5}\right)-\mathrm{O}-\right), 1.7-2.8\left(9 \mathrm{H}\right.$, multiplet, $\mathrm{C}_{6} \mathrm{H}_{5}-$ and $\left.-\mathrm{C}_{6} \mathrm{H}_{4^{-}}\right)$. Anal. Calcd. for $\mathrm{C}_{17} \mathrm{H}_{17} \mathrm{O}_{4} \mathrm{~N}: \mathrm{C}, 68.21 ; \mathrm{H}$, $5.73 ; \mathrm{N}, 4.68$. Found: $\mathrm{C}, 68.09 ; \mathrm{H}, 5.71 ; \mathrm{N}, 4.77$.

threo-2-Methyl-1-phenyl-1,3-propanediol 0,0-Di-p-nitrobenzoate (threo-XXVI)—Ketone (IV) (6.56 g, 40 mmoles) was reduced with $\mathrm{NaBH}_{4}(800 \mathrm{mg}, 20 \mathrm{mmoles})$ in EtOH $(100 \mathrm{ml})$ at room temperature and 
treated as usual to give an oily product $(6.18 \mathrm{~g})$. This oil was mixed with $p$-nitrobenzoyl chloride (15.2 g, $81.8 \mathrm{mmoles})$ in pyridine $(150 \mathrm{ml})$. The whole was heated on a water-bath for $4 \mathrm{hr}$, then was kept at room temperature overnight. The pyridine was evaporated in vacuo, after which residue was taken up in $\mathrm{CHCl}_{3}$, washed with $10 \%$ aq. $\mathrm{NaOH}, \mathrm{H}_{2} \mathrm{O}$, and dried over anhyd. $\mathrm{Na}_{2} \mathrm{SO}_{4}$. Evaporation of the $\mathrm{CHCl}_{3}$ afforded a pale yellow oil $(7.5 \mathrm{~g})$, which was treated again with $p$-nitrobenzoyl chloride $(7.6 \mathrm{~g}, 41 \mathrm{mmoles})$, as above. The oily neutral fraction was dissolved in hot benzene $(c a .100 \mathrm{ml})$ and was allowed to cool to room temperature to give a solid $(4.89 \mathrm{~g})$. This solid was recrystallized 6 times from benzene to give pale yellow prisms

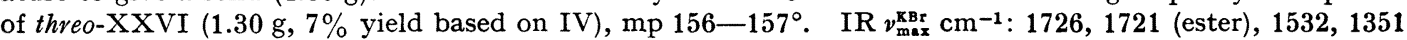
(nitro), 1269 (ester). Anal. Calcd. for $\mathrm{C}_{24} \mathrm{H}_{20} \mathrm{O}_{8} \mathrm{~N}_{2}: \mathrm{C}, 62.02 ; \mathrm{H}, 4.34 ; \mathrm{N}, 6.03$. Found: C, 62.18; $\mathrm{H}, 4.60$; $\mathrm{N}, 5.82$.

threo-2-Methyl-1-phenyl-1,3-propanediol (threo-XII) —A solution of threo-XXVI (930 mg, 2 mmoles) and $\mathrm{NaOH}(220 \mathrm{mg}, 5.5 \mathrm{mmoles})$ in $\mathrm{EtOH}(30 \mathrm{ml})$ and $\mathrm{H}_{2} \mathrm{O}(3 \mathrm{ml})$ was refluxed for $1.5 \mathrm{hr}$, then evaporated in vacuo to dryness. The residue was dissolved in $\mathrm{H}_{2} \mathrm{O}(15 \mathrm{ml})$ and extracted continuously with ether. The ether was dried and evaporated to dryness to give threo-XII ( $310 \mathrm{mg}, 93 \%$ yield) as an oil. NMR (in AcOH, $60 \mathrm{MHz}) \tau: 9.17\left(3 \mathrm{H}\right.$, doublet, $\left.J=6.8 \mathrm{~Hz}, \mathrm{CH}_{3}-\mathrm{CH}-\right),-6.4\left(2 \mathrm{H}\right.$, multiplet, $\left.-\mathrm{CH}-\mathrm{CH}_{2} \mathrm{O}-\right), 5.05$ (1 $\mathrm{H}$, doublet, $\left.J=4.2 \mathrm{~Hz}, \mathrm{C}_{6} \mathrm{H}_{5}-\mathrm{CH}(\mathrm{OH})-\mathrm{CH}-\right), 2.70\left(5 \mathrm{H}\right.$, singlet, $\left.\mathrm{C}_{6} \mathrm{H}_{5}-\right)$.

threo-2,2,5-Trimethyl-4-phenyl-1,3-dioxane (threo-XXXII): This sample was prepared from threo-XII using a procedure similar to the synthesis of erythro-XXXII, then it was distilled at $25 \mathrm{mmHg}$ with a bath temperature of $160-170^{\circ}$. NMR (in $\left.\mathrm{CCl}_{4}, 60 \mathrm{MHz}\right) \tau: 9.22\left(3 \mathrm{H}\right.$, doublet, $\left.J=6 \mathrm{~Hz}, \mathrm{CH}_{3}-\mathrm{CH}-\right), 6.36(1 \mathrm{H}$, doublet-doublet, $J=11.3$ and $\left.1.5 \mathrm{~Hz},-\mathrm{O}-\mathrm{CH}_{2}-\mathrm{CH}-\right), 5.75\left(1 \mathrm{H}\right.$, doublet-doublet, $J=11.3$ and $2.3 \mathrm{~Hz},-\mathrm{O}-\mathrm{CH}_{2}-$ $\mathrm{CH}-), 4.91\left(1 \mathrm{H}\right.$, doublet, $\left.J=2.3 \mathrm{~Hz}, \mathrm{C}_{6} \mathrm{H}_{5}-\mathrm{CH}(\mathrm{O}-)-\mathrm{CH}-\right), 2.76\left(5 \mathrm{H}\right.$, singlet, $\left.\mathrm{C}_{6} \mathrm{H}_{5^{-}}\right)$. Anal. Calcd. for $\mathrm{C}_{13} \mathrm{H}_{18^{-}}$ $\mathrm{O}_{2}: \mathrm{C}, 75.69 ; \mathrm{H}, 8.80$. Found $\mathrm{C}, 75.51 ; \mathrm{H}, 8.79$.

threo-2,3-Diamino-1-phenyl-1-propanol (threo-XIV)—threo-Phenylserine amide (mp 123.5-124.5 ${ }^{\circ}$ (reported ${ }^{15)} \mathrm{mp} 118-120^{\circ}$ ), IR $\nu_{\max }^{\mathrm{KBr}} \mathrm{cm}^{-1}: 3350,3200(\mathrm{OH}$ and $\mathrm{NH}), 1667,1606$ (amide)) (1.08 g, $\left.6 \mathrm{mmoles}\right)$ was reduced with $\mathrm{LiAlH}_{4}(1.65 \mathrm{~g}, 42 \mathrm{mmoles})$ in THF $(80 \mathrm{ml})$ in the usual manner to give threo-XIV (440 $\mathrm{mg}, 56 \%$ yield) as a colorless liquid. NMR (in $\mathrm{AcOH}, 60 \mathrm{MHz}) \tau: 5.00\left(1 \mathrm{H}\right.$, doublet, $J=c a .6 \mathrm{~Hz}, \mathrm{C}_{6} \mathrm{H}_{5}$ $\mathrm{CH}(\mathrm{OH})-\mathrm{CH}-)$.

$\mathrm{N}^{2}, \mathrm{~N}^{3}$-Dibenzamide: A solution of threo-XIV $(440 \mathrm{mg}, 2.66 \mathrm{mmoles})$ and benzoyl chloride (1.31 g, $9.3 \mathrm{mmoles})$ in pyridine $(30 \mathrm{ml})$ was refluxed for $3 \mathrm{hr}$, and evaporated to dryness. The residue was taken up in $\mathrm{CHCl}_{3}$, washed with $10 \%$ aq. $\mathrm{HCl}$, satd. aq. $\mathrm{NaHCO}_{3}, \mathrm{H}_{2} \mathrm{O}$, dried over anhyd. $\mathrm{Na}_{2} \mathrm{SO}_{4}$, and the $\mathrm{CHCl}_{3}$ solution was evaporated to dryness in vacuo to afford an oil $(890 \mathrm{mg})$. This oil was dissolved in a solution of $\mathrm{KOH}(170 \mathrm{mg}, 3 \mathrm{mmoles})$ in $\mathrm{EtOH}(17 \mathrm{ml})$ and the whole was refluxed for $2.5 \mathrm{hr}$. After evaporation of the solvent, the residue was taken up in $\mathrm{CHCl}_{3}$, washed with satd. aq. $\mathrm{NaHCO}, 10 \%$ aq. $\mathrm{HCl}$, $\mathrm{H}_{2} \mathrm{O}$, dried, and evaporated to give a solid. Recrystallization of the solid from EtOH afforded colorless needles of $\mathrm{N}^{2}, \mathrm{~N}^{3}$-dibenzamide $\left(590 \mathrm{mg}, 60 \%\right.$ yield) of $\mathrm{mp} 195-197^{\circ}$. Recrystallizations twice from EtOH raised the mp to $199-200^{\circ}$. Anal. Calcd. for $\mathrm{C}_{23} \mathrm{H}_{22} \mathrm{O}_{3} \mathrm{~N}_{2}: \mathrm{C}, 73.78 ; \mathrm{H}, 5.92 ; \mathrm{N}, 7.48$. Found: C, 73.50; $\mathrm{H}, 5.93 ; \mathrm{N}, 7.42$.

A Mixture of Diastereomeric Methyl 2-Methoxy-3-phenylhydracrylate (XXVII) - A solution of $\mathrm{Et} \mathrm{t}_{2} \mathrm{NH}$ $(22.0 \mathrm{~g}, 0.3 \mathrm{~mole})$ in ether $(40 \mathrm{ml})$ was added to a Grignard solution prepared from $\mathrm{EtBr}(32.7 \mathrm{~g}, 0.3 \mathrm{~mole})$ and $\mathrm{Mg}$ (7.3 g, 0.3 atom) in ether $(120 \mathrm{ml})$, and the whole was stirred at room temperature for $30 \mathrm{~min}$ and at reflux temperature for $30 \mathrm{~min}$. After cooling to $-5^{\circ}$, a solution of benzaldehyde $(10.6 \mathrm{~g}, 0.1 \mathrm{~mole})$ and methyl methoxyacetate $(10.4 \mathrm{~g}, 0.1 \mathrm{~mole})$ in ether $(90 \mathrm{ml})$ was added to the above solution, and the whole was stirred at $-5^{\circ}$ for $2 \mathrm{hr}$. Initially, a viscous creamy oil separated, which gradually became powderlike precipitates. The reaction mixture was decomposed with satd. aq. $\mathrm{NH}_{4} \mathrm{Cl}(30 \mathrm{ml})$, the insolubles were filtered off and washed with ether. The combined filtrate and the washings were successively washed with $10 \%$ aq. $\mathrm{H}_{2} \mathrm{SO}_{4}$, satd. aq. $\mathrm{NaHSO}_{3}$, satd. aq. $\mathrm{NaHCO}_{3}$, and satd. aq. $\mathrm{NaCl}$. Evaporation of the dried ether solution followed by distillation of the residue at reduced pressure afforded XXVII (3.1 g, 15\% yield), bp $120-130^{\circ}(3 \mathrm{mmHg})$. IR $\nu_{\max }^{11 \mathrm{iq} .} \mathrm{cm}^{-1}:-3400(\mathrm{OH}), 2815\left(\mathrm{OCH}_{3}\right), 1745$ (ester).

erythro-2-Methoxy-3-phenylhydracrylamide (erythro-XXVIII)—A solution of XXVII (4.67g) in $\mathrm{MeOH}$ $(100 \mathrm{ml})$ satd. with $\mathrm{NH}_{3}$ was closed tightly and allowed to stand at $c a .30^{\circ}$ for 2 days. Evaporation of the solvent in vacuo gave a solid, which was recrystallized from AcOEt to afford crude erythro-XXVIII (2.1 g, $48.5 \%$ yield) as colorless prisms of $\mathrm{mp} 153-155^{\circ}$. Two recrystallizations from AcOEt afforded colorless prisms of $\mathrm{mp} 157.5-158.5^{\circ}$. IR $v_{\max }^{\mathrm{KBr}} \mathrm{cm}^{-1}: 3375,3190(\mathrm{OH}$ and $\mathrm{NH}), 2815\left(\mathrm{OCH}_{3}\right),-1640$ (amide). Anal. Calcd. for $\mathrm{C}_{10} \mathrm{H}_{13} \mathrm{O}_{3} \mathrm{~N}: \mathrm{C}, 61.52 ; \mathrm{H}, 6.71 ; \mathrm{N}, 7.18$. Found: $\mathrm{C}, 61.63 ; \mathrm{H}, 6.93 ; \mathrm{N}, 7.10$.

erythro-2-Methoxy-3-phenylhydracrylic Acid (erythro-XXIX)—A mixture of erythro-XXVIII (780 mg) and $10 \%$ aq. $\mathrm{HCl}(15 \mathrm{ml})$ was refluxed for $2.5 \mathrm{hr}$. After cool, the reaction mixture was extracted continuously with ether. The ether was dried and evaporated to give a solid, which was recrystallized from $\mathrm{CHCl}_{3}-$ hexane to colorless plates of erythro-XXIX $\left(470 \mathrm{mg}, 60 \%\right.$ yield) of $\mathrm{mp} 104-107^{\circ}$. Further recrystallizations raised the $\mathrm{mp}$ to $104.5-107^{\circ}$. Anal. Calcd. for $\mathrm{C}_{10} \mathrm{H}_{12} \mathrm{O}_{4}: \mathrm{C}, 61.21 ; \mathrm{H}, 6.17$. Found: $\mathrm{C}, 61.35 ; \mathrm{H}, 6.04$. erythro-2-Methoxy-1-phenyl-1,3-propanediol (erythro-XV)—The reduction of erythro-XXIX (310 mg, $1.58 \mathrm{mmoles})$ with $\mathrm{LiAlH}_{4}(165 \mathrm{mg}, 4.32 \mathrm{mmoles})$ in THF $(50 \mathrm{ml})$ was performed in the usual manner to give erythro-XV (280 mg, 97\% yield) as a colorless oil. NMR (in AcOH, $60 \mathrm{MHz}) \tau: 6.71\left(3 \mathrm{H}\right.$, singlet, $\left.-\mathrm{OCH}_{3}\right)$, $5.08\left(1 \mathrm{H}\right.$, doublet, $\left.J=5.4 \mathrm{~Hz}, \mathrm{C}_{6} \mathrm{H}_{5}-\mathrm{CH}(\mathrm{OH})-\mathrm{CH}-\right)$, $2.61\left(5 \mathrm{H}\right.$, singlet, $\left.\mathrm{C}_{6} \mathrm{H}_{5}^{-}\right)$. 
erythro-2,2-Dimethyl-5-methoxy-4-phenyl-1,3-dioxane (erythro-XXXI)：This sample was prepared from erythro-XV in a manner similar to the synthesis of threo-XXXI described below, then it was distilled at $21 \mathrm{mmHg}$ under a bath temperature of $160-170^{\circ}$ to erythro-XXXI in $86 \%$ yield. NMR (in $\mathrm{CCl}_{4}, 60 \mathrm{MHz}^{2}$ $\tau$ : $8.62\left(3 \mathrm{H}\right.$, singlet, $\left.\mathrm{CH}_{3}-\mathrm{C}\right), 8.52\left(3 \mathrm{H}\right.$, singlet, $\left.\mathrm{CH}_{3}-\mathrm{C}\right), 7.02\left(3 \mathrm{H}\right.$, singlet, $\left.-\mathrm{OCH}_{3}\right), 5.53(1 \mathrm{H}$, doublet, $J=9$ $\left.\mathrm{Hz}, \mathrm{C}_{6} \mathrm{H}_{5}-\mathrm{CH}(\mathrm{O}-)-\mathrm{CH}-\right), 2.72\left(5 \mathrm{H}\right.$, singlet, $\left.\mathrm{C}_{6} \mathrm{H}_{5}-\right)$. Anal. Calcd. for $\mathrm{C}_{13} \mathrm{H}_{18} \mathrm{O}_{3}: \mathrm{C}, 70.24 ; \mathrm{H}, 8.16$. Found: $\mathrm{C}, 70.01 ; \mathrm{H}, 8.33$.

erythro-5-Methoxy-2-(p-nitrophenyl)-4-phenyl-1,3-dioxane (erythro-XXXII): A solution of erythro-XV ( $260 \mathrm{mg}, 1.4 \mathrm{mmoles})$, $p$-nitrobenzaldehyde ( $230 \mathrm{mg}, 1.5 \mathrm{mmoles})$ and conc. $\mathrm{H}_{2} \mathrm{SO}_{4}$ (1 drop) in dehyd. xylene was treated as in the synthesis of erythro-XXXIV, and the product was recrystallized from hexane to afford pale yellow prisms of erythro-XXXII $\left(220 \mathrm{mg}, 50 \%\right.$ yield) of mp $96-98^{\circ}$. IR $v_{\max }^{\mathrm{KBr}} \mathrm{cm}^{-1}: 2835\left(\mathrm{OCH}_{3}\right), 1516$, 1356 (nitro). NMR (in $\left.\mathrm{CDCl}_{3}, 100 \mathrm{MHz}\right) \tau: 6.98\left(3 \mathrm{H}\right.$, singlet, $\left.\mathrm{OCH}_{3}\right), 6.37\left(1 \mathrm{H}\right.$, triplet, $J=10.2 \mathrm{~Hz},-\mathrm{O}_{-} \mathrm{CH}_{2}-$ $\mathrm{CH}-), 5.64\left(1 \mathrm{H}\right.$, doublet-doublet, $J=5.0$ and $\left.10.2 \mathrm{~Hz},-\mathrm{O}-\mathrm{CH}_{2}-\mathrm{CH}-\right), 5.57\left(1 \mathrm{H}\right.$, doublet, $J=8.1 \mathrm{~Hz}, \mathrm{C}_{6} \mathrm{H}_{5}-$ $\mathrm{CH}(\mathrm{O}-)-\mathrm{CH}-), 4.47\left(1 \mathrm{H}\right.$, singlet, $\left.-\mathrm{O}-\mathrm{CH}\left(\mathrm{C}_{6} \mathrm{H}_{4}-\mathrm{NO}_{2}\right)-\mathrm{O}-\right)$. Anal. Calcd. for $\mathrm{C}_{17} \mathrm{H}_{17} \mathrm{O}_{5} \mathrm{~N}: \mathrm{C}, 64.75 ; \mathrm{H}, 5.43$; $\mathrm{N}$, 4.44. Found: $\mathrm{C}, 64.95 ; \mathrm{H}, 5.53 ; \mathrm{N}, 4.49$.

threo-2-Methoxy-1-phenyl-1,3-propanediol 0,0-Di-p-nitrobenzoate (threo-XXX)—The ketone (VII) $(3.0 \mathrm{~g}, 16.7 \mathrm{mmoles})$ was reduced with $\mathrm{NaBH}_{4}(680 \mathrm{mg}, 17 \mathrm{mmoles})$ in EtOH $(80 \mathrm{ml})$ at room temperature and treated in the usual manner to afford an oily product, which was mixed with $p$-nitrobenzoyl chloride $(7.4 \mathrm{~g}, 40 \mathrm{mmoles})$ in pyridine $(100 \mathrm{ml})$, and the whole was refluxed for $4 \mathrm{hr}$. The pyridine was evaporated in vacuo and the residue was treated as usual to give an oil $(6.5 \mathrm{~g})$ as a neutral component. The oil was dissolved in AcOEt $(50 \mathrm{ml})$, then hexane $(c a .50 \mathrm{ml})$ was added and the whole was allowed to stand at room temperature overnight. The deposited solid $(2.29 \mathrm{~g})$ of $\mathrm{mp} 99-103^{\circ}$ was recrystallized 6 times from AcOEt to give pale yellow prisms of threo-XXX $(0.73 \mathrm{~g}, 14 \%$ yield $)$ of $\mathrm{mp} 162.5-164^{\circ}$. IR $\nu_{\max }^{\mathrm{KBr}} \mathrm{cm}^{-1}: 2830\left(\mathrm{OCH}_{3}\right)$, 1732 (ester), 1526, 1351 (nitro). Anal. Calcd. for $\mathrm{C}_{24} \mathrm{H}_{20} \mathrm{O}_{9} \mathrm{~N}_{2}: \mathrm{C}, 60.00 ; \mathrm{H}, 4.20 ; \mathrm{N}, 5.83$. Found: C, 59.69; $\mathrm{H}, 4.17 ; \mathrm{N}, 5.91$.

threo-2-Methoxy-1-phenyl-1,3-propanediol (threo-XV)—A solution of threo-XXX (1.25 g, $2.6 \mathrm{mmoles})$ and $\mathrm{NaOH}(240 \mathrm{mg}, 6 \mathrm{mmoles})$ in $\mathrm{EtOH}(34 \mathrm{ml})$ and $\mathrm{H}_{2} \mathrm{O}(5 \mathrm{ml})$ was refluxed for $1.5 \mathrm{hr}$, then evaporated to dryness. The residue was dissolved in $\mathrm{H}_{2} \mathrm{O}(15 \mathrm{ml})$ and the whole was extracted continuously with ether. The ether extracts was dried over anhyd. $\mathrm{Na}_{2} \mathrm{SO}_{4}$, and evaporated to dryness in vacuo to afford threo-XV (460 mg, 97\% yield) as a colorless oil. NMR (in AcOH, $60 \mathrm{MHz}) \tau: 6.59\left(3 \mathrm{H}\right.$, singlet, $\left.-\mathrm{OCH}_{3}\right), 5.08(1 \mathrm{H}$, doublet, $\left.J=5.4 \mathrm{~Hz}, \mathrm{C}_{6} \mathrm{H}_{5}-\mathrm{CH}(\mathrm{OH})-\mathrm{CH}-\right), 2.61\left(5 \mathrm{H}\right.$, singlet, $\mathrm{C}_{6} \mathrm{H}_{5}-$ ).

threo-2,2-Dimethyl-5-methoxy-4-phenyl-1,3-dioxane (threo-XXXI): A mixture of threo-XV (280 mg), anhyd. $\mathrm{CuSO}_{4}(800 \mathrm{mg})$ and dehyd. acetone $(20 \mathrm{ml})$ was stirred at room temperature for 3 days. Insoluble materials were filtered off, and washed with a small amount of acetone. The combined filtrate and the washings were evaporated to dryness. The residual oil $(270 \mathrm{mg})$ was chromatographed on silica gel (27 g) with benzene-AcOEt $(2: 1)$ to give threo-XXXI $(180 \mathrm{mg}, 53 \%$ yield) as a colorless oil which was distilled

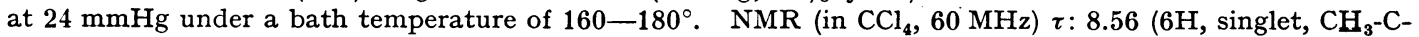
$\left.\mathrm{CH}_{3}\right), 7.03\left(3 \mathrm{H}\right.$, singlet, $\left.-\mathrm{OCH}_{3}\right), 5.10\left(1 \mathrm{H}\right.$, doublet $\left.J=2.3 \mathrm{~Hz}, \mathrm{C}_{6} \mathrm{H}_{5}-\mathrm{CH}(\mathrm{O}-)-\mathrm{CH}-\right), 2.68\left(5 \mathrm{H}\right.$, singlet, $\left.\mathrm{C}_{6} \mathrm{H}_{5}-\right)$. Anal. Calcd. for $\mathrm{C}_{13} \mathrm{H}_{18} \mathrm{O}_{3}$ : C, 70.24; $\mathrm{H}, 8.16$. Found: $\mathrm{C}, 69.98 ; \mathrm{H}, 8.10$.

threo-5-Methoxy-2-( $p$-nitrophenyl)-4-phenyl-1,3-dioxane (threo-XXXII): This sample was prepared from threo-XV in a manner similar to the synthesis of erythro-XXXIV. Recrystallizations from hexane afforded threo-XXXII in $60 \%$ yield as pale yellow prisms of mp 133.5-135 . IR $\nu_{\max }^{\mathrm{KBr}} \mathrm{cm}^{-1}: 2820\left(\mathrm{OCH}_{3}\right)$, 1523, 1346 (nitro). NMR (in $\left.\mathrm{CDCl}_{3}, 100 \mathrm{MHz}\right) \tau: 6.83\left(3 \mathrm{H}\right.$, singlet, $\left.-\mathrm{OCH}_{3}\right),-5.81(1 \mathrm{H}$, doublet-doublet, $J=12.3$ and $\left.1.8 \mathrm{~Hz},-\mathrm{O}-\mathrm{CH}_{2}-\mathrm{CH}-\right),-5.44\left(1 \mathrm{H}\right.$, doublet-doublet, $J=12.3$ and $\left.1.8 \mathrm{~Hz},-\mathrm{O}-\mathrm{CH}_{2}-\mathrm{CH}_{-}\right), 4.91$ $\left(1 \mathrm{H}\right.$, doublet, $\left.J=2.1 \mathrm{~Hz}, \mathrm{C}_{6} \mathrm{H}_{5}-\mathrm{CH}(\mathrm{O}-)-\mathrm{CH}-\right), 4.16\left(1 \mathrm{H}\right.$, singlet, $\left.-\mathrm{O}-\mathrm{CH}\left(\mathrm{C}_{6} \mathrm{H}_{4}-\mathrm{NO}_{2}\right)-\mathrm{O}-\right)$. Anal. Calcd. for $\mathrm{C}_{17} \mathrm{H}_{17} \mathrm{O}_{5} \mathrm{~N}: \mathrm{C}, 64.75 ; \mathrm{H}, 5.43 ; \mathrm{N}, 4.44$. Found: $\mathrm{C}, 65.02 ; \mathrm{H}, 5.56 ; \mathrm{N}, 4.25$.

erythro-3-Amino-2-methyl-1-phenyl-1-propanol (erythro-XVI) —A mixture of erythro-XXVIII (255 mg, 1.31 mmoles) and $\mathrm{LiAlH}_{4}(250 \mathrm{mg}, 6.55 \mathrm{mmoles})$ in THF $(45 \mathrm{ml})$ was refluxed for $5 \mathrm{hr}$, then left at room temperature overnight. A solution of $10 \%$ aq. $\mathrm{NaOH}(0.4 \mathrm{ml})$ and $\mathrm{H}_{2} \mathrm{O}(0.85 \mathrm{ml})$ was added to the reaction mixture. The insoluble materials were filtered off, and washed with a small amount of THF. The filtrate and the washings were combined and evaporated in vacuo to leave an oil, which was dissolved in $10 \%$ aq. $\mathrm{HCl}(20 \mathrm{ml})$. After washing with $\mathrm{CHCl}_{3}$ and benzene, the aqueous layer was evaporated to dryness in vacuo and the residue was taken up in $\mathrm{CHCl}_{3}$. $\quad \mathrm{NH}_{3}$ gas in excess was introduced to the $\mathrm{CHCl}_{3}$ solution. Deposited precipitates were filtered off and washed with a small amount of $\mathrm{CHCl}_{3}$. Evaporation of the combined filtrate and the washings in vacuo to dryness gave erythro-XVI (185 mg, 79\% yield) as a pale yellow liquid. NMR (in AcOH, $60 \mathrm{MHz}) \tau: 6.65\left(3 \mathrm{H}\right.$, singlet, $\left.-\mathrm{OCH}_{3}\right), 5.00\left(1 \mathrm{H}\right.$, doublet, $\left.J=4.5 \mathrm{~Hz}, \mathrm{C}_{6} \mathrm{H}_{5}-\mathrm{CH}(\mathrm{OH})-\mathrm{CH}-\right)$, 2.67 (5H, singlet, $\mathrm{C}_{6} \mathrm{H}_{5}-$ ).

erythro-5-Methoxy-6-phenyl-1,3-oxazin-2-one: A mixture of erythro-XVI (350 $\mathrm{mg}, 1.93 \mathrm{mmoles}$ ) in benzene $(10 \mathrm{ml}), 10 \%$ aq. $\mathrm{KOH}(5.6 \mathrm{ml})$ and $19 \%(\mathrm{w} / \mathrm{w}) \mathrm{COCl}_{2}$ solution in toluene $(3.5 \mathrm{ml})$ was shaken vigorously for $10 \mathrm{~min}$. The organic layer was separated, washed with $\mathrm{H}_{2} \mathrm{O}$, dried over anhyd. $\mathrm{Na}_{2} \mathrm{SO}_{4}$, and evaporated to dryness in vacuo. The residue was recrystallized from benzene-hexane to afford erythro-5-methoxy6-phenyl-1,3-oxazin-2-one (190 mg, 45\% yield) of $\mathrm{mp} 148.5-150^{\circ}$. IR $\boldsymbol{\nu}_{\max }^{\mathrm{KBr}} \mathrm{cm}^{-1}: 2825\left(\mathrm{OCH}_{3}\right), 1706(\mathrm{C}=\mathrm{O})$. Anal. Calcd. for $\mathrm{C}_{11} \mathrm{H}_{13} \mathrm{O}_{3} \mathrm{~N}: \mathrm{C}, 63.75 ; \mathrm{H}, 6.32 ; \mathrm{N}, 6.76$. Found: C, 63.70; H, 7.24; N, 6.61. 
erythro-2-Methoxy-1-phenyl-1-propanol (erythro-XI)__-A diastereomeric mixture of 2-methoxy-1phenyl-1-propanol, obtained form III by $\mathrm{LiAlH}_{4}$ reduction in the usual manner, was subjected to preparative gas chromatography using a column of $20 \%$ carbowax $20 \mathrm{M}$ on C-22 $(1 \mathrm{~cm}$ in diameter and $4.5 \mathrm{~m}$ in length) at $198^{\circ}$ Of the two incompletely separated peaks that appeared at $t_{\mathrm{R}} 45 \mathrm{~min}$ to $t_{\mathrm{R}} 60 \mathrm{~min}$, the latter peak $\left(t_{\mathrm{R}} 55 \mathrm{~min}\right.$ to $t_{\mathrm{R}} 60 \mathrm{~min}$ ) was collected and distilled to give erythro-XI of bp $104-105^{\circ}(5 \mathrm{mmHg}) . \mathrm{Gas}$ chromatographic analysis showed that the diastereomeric purity of this sample was not less than $97 \%$. IR $\nu_{\max }^{\text {11q. }} \mathrm{cm}^{-1}: 3440(\mathrm{OH}), 2830\left(\mathrm{OCH}_{3}\right) . \quad \mathrm{NMR}$ (in $\left.\mathrm{AcOH}, 60 \mathrm{MHz}\right) \tau: 8.96\left(3 \mathrm{H}\right.$, doublet, $\left.J=6.3 \mathrm{~Hz}, \mathrm{CH}_{3}-\mathrm{CH}_{-}\right)$, $6.65\left(3 \mathrm{H}\right.$, singlet, $\left.-\mathrm{OCH}_{3}\right), \sim 6.3\left(1 \mathrm{H}\right.$, multiplet, $\left.\mathrm{CH}_{3}-\mathrm{CH}\left(\mathrm{OCH}_{3}\right)-\mathrm{CH}-\right), 5.09\left(1 \mathrm{H}\right.$, doublet, $J=4.5 \mathrm{~Hz}_{2} \mathrm{C}_{6} \mathrm{H}_{5}$ $\mathrm{CH}(\mathrm{OH})-\mathrm{CH}-), 2.70\left(5 \mathrm{H}\right.$, singlet, $\left.\mathrm{C}_{6} \mathrm{H}_{5}-\right)$. Anal. Calcd. for $\mathrm{C}_{10} \mathrm{H}_{14} \mathrm{O}_{2}: \mathrm{C}, 72.26 ; \mathrm{H}, 8.49$. Found: C, 72.23; $\mathrm{H}, \mathbf{8 . 4 3}$.

erythro-1,2-Dimethoxy-1-phenylpropane (erythro-XXXV)—a) A suspension of $\mathrm{NaH}$ (obtained from $1.06 \mathrm{~g}$ (22 mmoles) of a $50 \%$ oil dispersion by washing it with dehyd. xylene and dioxane) in dioxane $(20 \mathrm{ml})$

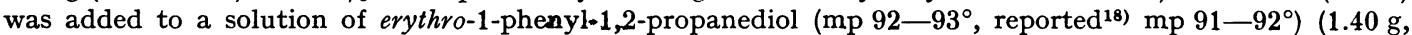
$9.2 \mathrm{mmoles})$ in dioxane $(30 \mathrm{ml})$, and the whole was stirred at room temperature for $40 \mathrm{~min}$. $\mathrm{CH}_{3} \mathrm{I}(4.9 \mathrm{ml}$, ca. $80 \mathrm{mmoles}$ ) was added to this mixture and the whole was allowed to stand at room temperature overnight. Insoluble materials were filtered off, and the filtrate was evaporated to dryness under reduced pressure. The reddish-yellow residue was subjected to column chromatography on silica gel with benzene to give a pale yellow oil $(1.1 \mathrm{~g})$, which was distilled to the colorless oil of erythro-XXXV (900 mg, $54 \%$ yield) of bp $88-89^{\circ}(9 \mathrm{mmHg})$. IR $\nu_{\max }^{11 \mathrm{lq} .} \mathrm{cm}^{-1}: 2820\left(\mathrm{OCH}_{3}\right), 1114$ (ether). NMR (in $\left.\mathrm{CCl}_{4}, 60 \mathrm{MHz}\right) \tau: 8.87$ (3H, doublet, $\left.J=6 \mathrm{~Hz}, \mathrm{CH}_{3}-\mathrm{CH}-\right)$, $6.91\left(3 \mathrm{H}\right.$, singlet, $\left.-\mathrm{OCH}_{3}\right), 6.81\left(1 \mathrm{H}\right.$, singlet, $\left.-\mathrm{OCH}_{3}\right), \sim 6.7\left(1 \mathrm{H}\right.$, multiplet, $\mathrm{CH}_{3}-\mathrm{CH}_{-}$ $\left.\left(\mathrm{OCH}_{3}\right)-\mathrm{CH}-\right), 6.05\left(1 \mathrm{H}\right.$, doublet, $\left.J=6 \mathrm{~Hz}, \mathrm{C}_{6} \mathrm{H}_{5}-\mathrm{CH}\left(\mathrm{OCH}_{3}\right)-\mathrm{CH}-\right), 2.77\left(5 \mathrm{H}\right.$, singlet, $\left.\mathrm{C}_{6} \mathrm{H}_{5}-\right)$. Anal. Calcd. for $\mathrm{C}_{11} \mathrm{H}_{16} \mathrm{O}_{2}$ : C, 73.30; $\mathrm{H}, 8.95$. Found: $\mathrm{C}, 73.06 ; \mathrm{H}, 8.96$.

b) erythro-XI $(1.40 \mathrm{~g}, 8.4 \mathrm{mmoles})$ obtained as above was treated with $\mathrm{NaH}(480 \mathrm{mg}$ as a $50 \%$ oil dispersion, 10 mmoles) and $\mathrm{CH}_{3} \mathrm{I}(2.5 \mathrm{ml}, c a .40 \mathrm{mmoles})$ in dioxane $(50 \mathrm{ml})$ as in a) to give erythro-XXXV (310 $\mathrm{mg}, 20 \%$ yield) as a colorless liquid. This sample was shown to be identical with the sample obtained in a) by comparing their IR and NMR spectra.

Examination of the NMR Method for Analyses of the Ratios of Diasteromeric Mixture of threo-XI and erythro-XI-Sample of known compositions of diasteromers(sample a: $99.3 \mathrm{mg}$ of erythro-IX and $11.0 \mathrm{mg}$ of threo-IX in $0.55 \mathrm{ml}$ of $\mathrm{AcOH}$; sample b: $230.3 \mathrm{mg}$ of erythro-IX and $10.6 \mathrm{mg}$ of threo-IX in $1.20 \mathrm{ml}$ of $\mathrm{AcOH})$ were prepared and their NMR spectra $\left.(100 \mathrm{MHz})^{19}\right)$ were measured at $\tau 4$ to 6 , several times. Doublet peaks at $\tau 4.80$ (corresponding to erythro-IX) and at $\tau 5.33$ (corresponding to threo-IX) in the chart were cut out, and their weights were measured. A shown in Table IV, per cent compositions of the calculated and the found agreed within $2 \%$. The existence of threo-IX in sample b could also be detected by NMR operating at $60 \mathrm{MHz} .^{19)}$

TABLE IV. Estimations of Diastereomeric Ratios by NMR

\begin{tabular}{|c|c|c|c|c|c|c|c|c|c|c|}
\hline \multicolumn{2}{|c|}{ Sample } & \multirow{2}{*}{$\begin{array}{c}\text { Calcd. }(\%) \\
90.0\end{array}$} & \multicolumn{4}{|c|}{ Found $(\%)$} & \multicolumn{4}{|c|}{ Mean $(\%)$} \\
\hline a & erythro-IX & & 89.3, & 89.0 & 89.3 & 88.8 , & 88.8 & 89.4 & 88.7 & 89.0 \\
\hline & threo-IX & 10.0 & 10.7, & 11.0 & 10.7 & 11.2, & 11.2, & 10.6, & 11.3 & 11.0 \\
\hline \multirow[t]{2}{*}{$\mathrm{b}$} & erythro-IX & 95.6 & 94.1 & 93.3 & 94.5 & 94.0 & 93.9 & 93.8 & 92.7 & 93.9 \\
\hline & threo-IX & 4.4 & 5.9 , & 6.7 & 5.5 & 6.0 & 6.1, & 6.2 , & 7.3 & 6.1 \\
\hline
\end{tabular}

General Procedure for the Reduction of Ketones (I-VIII) with Sodium Borohydride-Reduction of ketones (1 mmoles) was carried out with $\mathrm{NaBH}_{4}(3 \mathrm{mmoles}$ for III, IV, and VII, $4 \mathrm{mmoles}$ for I, II, V, and VIII, 5 mmoles for VI) in EtOH $(20 \mathrm{ml})$ at reflux and ice-cooling $\left(1-4^{\circ}\right)$ temperatures. The reaction time was $5 \mathrm{hr}$ at reflux temperature, or 3 days at ice-cooling temperature. The reaction mixture was brought to $\mathrm{pH} 3$ with $10 \%$ aq. $\mathrm{HCl}$. Precipitates were filtered off, washed with a small amount of EtOH, and the combined filtrate and the washings were evaporated under reduced pressure. The residue was dissolved in $\mathrm{H}_{2} \mathrm{O}$, made alkaline with aq. $\mathrm{K}_{2} \mathrm{CO}_{3}$ when the reduction products were basic substances, and the whole was extracted continously with ether. The ether solution was dried over anhyd. $\mathrm{Na}_{2} \mathrm{SO}_{4}$, then evaporated to dryness under reduced pressure. Reduction products thus obtained were subjected to the above analytical procedures. In all experiments, the chemical yields of this reduction were not less than $94 \%$, except for $85 \%$ for VI.

Results of Analyses of the Ratios of Diastereomers_- Results are shown in Table III. Ratios of diastereomeric mixture in the reduction products of VII were determined from their O,O-diacetates by gas chromatography using 5\% PEGA on Diasolid L. Ratios of the diastereomeric mixture in the reduction products of VIII are given as rough measurements due to the incomplete separation of diastereomeric signals in their NMR spectra.

Acknowledgement The authors express their deep gratitude to Prof. T. Hino, University of Chiba, for measurements of NMR spectra $(100 \mathrm{MHz})$. 